\title{
Influence of biomass burning and anthropogenic emissions on ozone, carbon monoxide and black carbon at the Mt. Cimone GAW-WMO global station (Italy, 2165 m a.s.l.)
}

\author{
P. Cristofanelli ${ }^{1}$, F. Fierli ${ }^{1}$, A. Marinoni ${ }^{1}$, F. Calzolari ${ }^{1}$, R. Duchi ${ }^{1}$, J. Burkhart ${ }^{2}$, A. Stohl ${ }^{2}$, M. Maione ${ }^{3}$, J. Arduini ${ }^{3}$, \\ and P. Bonasoni ${ }^{1}$ \\ ${ }^{1}$ National Research Council of Italy, Institute of Atmospheric Sciences and Climate, Bologna, Italy \\ ${ }^{2}$ NILU - Norwegian Institute for Air Research, Kjeller, Norway \\ ${ }^{3}$ University of Urbino "Carlo Bo", Dipartimento di Scienze di Base e Fondamenti, Urbino, Italy \\ Correspondence to: P. Cristofanelli (p.cristofanelli@isac.cnr.it)
}

Received: 15 June 2012 - Published in Atmos. Chem. Phys. Discuss.: 21 August 2012

Revised: 5 December 2012 - Accepted: 21 December 2012 - Published: 3 January 2013

\begin{abstract}
This work investigates the variability of ozone $\left(\mathrm{O}_{3}\right)$, carbon monoxide $(\mathrm{CO})$ and equivalent black carbon (BC) at the Italian Climate Observatory "O. Vittori” (ICOOV), part of the Mt. Cimone global GAW-WMO station (Italy). For this purpose, ICO-OV observations carried out in the period January 2007-June 2009, have been analyzed and correlated with the outputs of the FLEXPART Lagrangian dispersion model to specifically evaluate the influence of biomass burning (BB) and anthropogenic emissions younger than 20 days. During the investigation period, the average $\mathrm{O}_{3}, \mathrm{CO}$ and $\mathrm{BC}$ at ICO-OV were $54 \pm 3 \mathrm{ppb}$, $122 \pm 7 \mathrm{ppb}$ and $213 \pm 34 \mathrm{ng} \mathrm{m}^{-3}$ (mean \pm expanded uncertainty with $p<95 \%$ ), with clear seasonal cycles characterized by summer maxima and winter minima for $\mathrm{O}_{3}$ and $\mathrm{BC}$ and spring maximum and summer minimum for $\mathrm{CO}$.

According to FLEXPART outputs, BB impact is maximized during the warm months from July to September but appeared to have a significant contribution to the observed tracers only during specific transport events. We characterised in detail five "representative" events with respect to transport scales (i.e. global, regional and local), source regions and $\mathrm{O}_{3}, \mathrm{CO}$ and $\mathrm{BC}$ variations. For these events, very large variability of enhancement ratios $\mathrm{O}_{3} / \mathrm{CO}$ (from -0.22 to 0.71 ) and $\mathrm{BC} / \mathrm{CO}$ (from 2.69 to $29.83 \mathrm{ng} \mathrm{m}^{-3} \mathrm{ppb}^{-1}$ ) were observed.

$\mathrm{CO}$ contributions related with anthropogenic emissions $\left(\mathrm{CO}_{\mathrm{ant}}\right)$ contributed to $17.4 \%$ of the mean $\mathrm{CO}$ value observed at ICO-OV, with the warm months appearing particu-
\end{abstract}

larly affected by transport events of air-masses rich in anthropogenic pollution. The proportion of tracer variability that is described by FLEXPART $\mathrm{CO}_{\text {ant }}$ peaked to $37 \%$ (in MaySeptember) for $\mathrm{CO}, 19 \%$ (in May-September) for $\mathrm{O}_{3}$ and $32 \%$ (in January-April) for BC. During May-September, the analysis of the correlation among $\mathrm{CO}, \mathrm{O}_{3}$ and $\mathrm{BC}$ as a function of the $\mathrm{CO}_{\text {ant }}$ indicated that ICO-OV was influenced by air-masses rich in anthropogenic pollution transported from the regional to the global scale. On the other side, $\mathrm{CO}$ and $\mathrm{O}_{3}$ were negatively correlated during October-December, when FLEXPART does not show significant presence of recent anthropogenic emissions and only a few observations are characterized by enhanced BC. Such behaviour may be attributed to an ensemble of processes concurrent in enhancing $\mathrm{O}_{3}$ with low $\mathrm{CO}$ (upper troposphere/lower stratosphere intrusions) and to $\mathrm{O}_{3}$ titration by $\mathrm{NO}$ in polluted air-masses along with lower photochemical activity. An intermediate situation occurs in January-April when $\mathrm{CO}$ and $\mathrm{O}_{3}$ were almost uncorrelated and $\mathrm{BC}$ enhancements were associated to relatively old (10 days) anthropogenic emissions.

\section{Introduction}

Tropospheric carbon monoxide $(\mathrm{CO})$, ozone $\left(\mathrm{O}_{3}\right)$ and black carbon (BC) have a substantial impact on climate and air quality. $\mathrm{CO}$, primarily emitted from combustion processes (also formed in substantial amounts from methane 
oxidation), strongly influences the abundance of the $\mathrm{OH}$ radical and thereby alters the lifetime of methane and other greenhouse gases (e.g., Seinfeld and Pandis, 1998; Forster et al., 2007). $\mathrm{O}_{3}$ is involved in photochemical reactions (e.g. Crutzen et al., 1999; Volz-Thomas et al., 2002) and in determining the overall oxidation capacity of the troposphere (Gauss et al., 2003). Moreover, it is a harmful pollutant (Conti et al., 2005) and an efficient greenhouse gas (Forster et al., 2007). Due to its direct impact on solar and thermal radiation, $\mathrm{BC}$ was recognised as an important factor contributing to global warming (Andreae and Gelencsér, 2006 and references therein). Additionally, $\mathrm{BC}$ causes an indirect radiative forcing by modifying the concentration and size spectrum of cloud droplets (e.g. Lohmann et al., 2000; Forster et al., 2007) and it decreases the surface albedo of snow (e.g. Flanner et al., 2009).

Southern Europe and the Mediterranean basin (hereafter SE/MB) are recognised as a hot-spot region both in terms of climate change (e.g. Forster et al., 2007) and air-quality (Monks et al., 2009), also representing a major crossroad of different air mass transport processes (Lelieveld et al., 2002; Millàn et al., 2006; Duncan et al., 2008). The transport of polluted air masses from Europe and other continents can influence the variability of trace gases and aerosol over SE/MB. In particular, large amounts of anthropogenic pollutants emitted in continental Europe are transported towards the SE/MB especially during summer (e.g. Duncan et al., 2008; Henne et al., 2005), when intense photochemical $\mathrm{O}_{3}$ production also occurs (see for instance Vautard et al., 2005). Moreover, in the past decades many studies have revealed significant intercontinental transport of air-masses rich in anthropogenic pollutants or biomass burning emissions from North America to Europe (e.g. Stohl and Trickl, 1999; Stohl et al., 2003, Auvray and Bay, 2005; Huntrieser et al., 2005). In particular, biomass burning (BB) represents a major source of atmospheric pollutants and climate altering species (e.g. Crutzen and Andreae, 1990; Simmonds et al., 2005) and forest wildfires have a considerable impact on the variability of $\mathrm{CO}, \mathrm{O}_{3}$ and BC in the Northern Hemisphere (e.g. Novelli et al., 2003; van der Werf et al., 2006; Bond et al., 2011). BC produced by boreal wildfires accounts for $10 \%$ of the annual anthropogenic $\mathrm{BC}$ emissions in the Northern Hemisphere (Bond et al., 2004). Previous studies have shown that the atmospheric compounds directly emitted by $\mathrm{BB}$ or produced by photochemical processes occurring within BB plumes can be transported over long distances, thus affecting both air quality and climate from local to global scales (e.g. Val Martin et al., 2006 and references therein). SE/MB can also be affected by large wildfire events in Europe, especially during summer (e.g. Pace et al., 2006; Cristofanelli et al., 2007; Turquety et al., 2009).

The pollutant budget in the Mediterranean basin may also vary due to climate change. A dryer and warmer climate in the Mediterranean region, as projected by climate models, can lead both to an increase in pollution sources such as wildfire events and to enhanced photochemical $\mathrm{O}_{3}$ production (Solomon et al., 2007) with a dramatic change in pollutant transport patterns over Europe (Forster et al., 2007).

In this work, we quantify the variability of $\mathrm{O}_{3}, \mathrm{CO}$ and $\mathrm{BC}$ over SE/MB from daily to seasonal timescales: observations are acquired on a routine basis at the Italian Climate Observatory "O. Vittori" (ICO-OV) of the Mt. Cimone global GAWWMO station (CMN, $44^{\circ} 11^{\prime} \mathrm{N}, 10^{\circ} 42^{\prime} \mathrm{E}, 2165 \mathrm{~m}$ a.s.l.) during the period 2007-2009. The ICO-OV location is considered representative for the baseline conditions of the Mediterranean free troposphere (Bonasoni et al., 2000; Fischer et al., 2003) and only during the warm months an influence of airmass transport from the regional boundary layer is detected due to convective processes and breeze regimes (Fischer et al., 2003; Van Dingenen et al., 2005). Three years of observations are analysed here to identify the role of BB (as done in Cristofanelli et al., 2009 for a specific event) and anthropogenic pollution transport to the observed compound variability. The Lagrangian atmospheric transport model FLEXPART provides an estimate of the emission age of $\mathrm{BB}$ and anthropogenic emissions at ICO-OV and, coupled to the observations, can allow to quantify the roles played by these emission types to the atmospheric composition variability.

\section{Experimental and methodologies}

\subsection{Observations}

At the ICO-OV, tropospheric $\mathrm{O}_{3}$ measurements have been carried out continuously since 1996 using a UV-photometric analyser (Dasibi 1108). The accuracy and quality of measurements (sampling time: $1 \mathrm{~min}$, combined standard uncertainty less than $\pm 2 \mathrm{ppb}$ in the range $1-100 \mathrm{ppb}$ ) and sampling procedures are guaranteed within the GAW requirements (WMO, 2002). In particular, the $\mathrm{O}_{3}$ analyser working at ICO-OV was traced back to SRP\#15 Standard Reference Photometer at EMPA (Swiss Federal Laboratories for Materials Testing and Research).

Since February 2007, CO mixing ratio is measured with a custom gas chromatograph equipped with a reduction gas detector (GC-RGD), Trace Analytical RGD2. The instrument has been running continuously since January 2007. Every $15 \mathrm{~min}$, an air sample is injected into the gas chromatograph for separation, and then analysed for CO via mercury oxide reduction and detection of mercury vapour by UV absorption. Each analysis sample is alternated with a calibration sample by means of real air working standards representative for ambient air mixing ratios for the Northern Hemispheric troposphere. The working standards were prepared at Max-Planck-Institute for Biogeochemistry in Jena and indirectly referenced against NOAA 2004 scale. This guarantees a continuous check of the detector calibration (Novelli, 1999) with an accuracy, in term of daily relative standard deviation over repeated analysis of the working standards (48 runs) of 
$0.72 \%$, total expanded uncertainty of $1.51 \%(k=2)$. RGD detectors are well-known to be affected by non-linear response. At CMN, a set of calibration standard with different $\mathrm{CO}$ mixing ratios were unavailable. Thus, we tested the nonlinearity of the GC-RGD system by inter-comparison with a GC-FID (Agilent GC6890) which was working in parallel at the measurement site since 2008, January. Even if only for the limited range of the typical mixing ratios observed at $\mathrm{CMN}$, correction functions were obtained (by mean of linear correlation between the two data-sets) and applied to the data series presented in this work.

Continuous measurements of equivalent BC (hereafter BC) are obtained by a multi-angle absorption photometer (MAAP 5012, Thermo Electron Corporation) since March 2006. The reduction of light transmission at $670 \mathrm{~nm}$, multiple reflection intensities, and air sample volume are continuously integrated over the sample run period to provide a real time data output (1 min resolution, variable integration time) of BC concentration (Petzold et al., 2002).

To neglect the variability related with annual to seasonal scales, not captured by FLEXPART, we calculated tracer anomalies $\left(\Delta \mathrm{O}_{3}, \Delta \mathrm{CO}, \Delta \mathrm{BC}\right)$ by subtracting a 21 -day running means from the 3 -h averaged values. These anomalies were used for the combined analyses with FLEXPART outputs. During the period January 2007-June 2009, for which FLEXPART outputs are available (with only a data gap in July 2008), data coverage of $76 \%, 97 \%$ and $72 \%$ have been achieved for $\mathrm{CO}, \mathrm{O}_{3}$ and $\mathrm{BC}$, respectively.

\subsection{FLEXPART simulations}

The Lagrangian particle dispersion model FLEXPART (Stohl et al., 2005) was used to quantify the impact of anthropogenic and $\mathrm{BB}$ emissions on the observed $\mathrm{CO}, \mathrm{BC}$ and $\mathrm{O}_{3}$ variability at ICO-OV. To this aim, 20 days backward (socalled "retroplume") simulations were done from ICO-OV location with a time resolution of $3 \mathrm{~h}$ (http://transport.nilu. no/projects/eucaari).

Every simulation consists of 40000 particles released in the volume of air sampled. The backward simulations are done with full turbulence and convection parameterizations. The FLEXPART retroplume output is proportional to the residence time of the particles in a given volume of air and corresponds to a potential emission sensitivity. When convolved with the gridded $\mathrm{CO}$ emission fluxes from an emission inventory, maps of potential source contributions are obtained. Integrating these maps over the globe or over certain regions of specific interest (e.g., Europe, North America), yields a model-calculated $\mathrm{CO}$ tracer mixing ratio at the ICO-OV location. Since FLEXPART does not account for $\mathrm{CO}$ emissions older than 20 days, this model-calculated $\mathrm{CO}$ can only explain a fraction of the $\mathrm{CO}$ mixing ratio observed at the ICO$\mathrm{OV}$, thus providing useful hints about specific contributions still not mixed within the tropospheric background. FLEXPART considers both $\mathrm{BB}$ (hereinafter $\mathrm{CO}_{\text {fire}}$ ) and anthro- pogenic $\mathrm{CO}$ emissions (hereinafter $\mathrm{CO}_{\text {ant }}$ ). $\mathrm{CO}_{\text {fire }}$ emissions are estimated from fire observations obtained from MODIS on board the Aqua and Terra NASA satellites (Justice et al., 2002; Giglio et al., 2003). Hot spots detected with a confidence of $75 \%$ or greater are used and combined with a land inventory with $1-\mathrm{km}$ resolution to provide an emissions inventory. It is assumed that area burned is 180 ha per fire detection. A parameterization was applied to determine the biomass available to burning, the fraction actually burned, and the emission factors, which are all dependent on land use (see Stohl et al., 2007, for a description). For $\mathrm{CO}_{\text {ant }}$, EDGAR version 3.2 emission inventory for the year 2000 (fast track) on a $1 \times 1$ degree grid was used outside North America and Europe. Over Europe, the EMEP emission inventory for the year 2005 with a resolution of 0.5 degree was used. Over most of North America, the inventory of Frost et al. (2006) was used.

For the purpose of systematically evaluating the influence at ICO-OV of BB and anthropogenic emissions with age less than 20 days and thus still not fully mixed within the atmospheric background, we analysed the time series of $\mathrm{CO}_{\text {fire }}$ and $\mathrm{CO}_{\text {ant }}$ emitted over the global domain.

FLEXPART also provides the information on the time spectrum of emission. In order to have a synthetic diagnostic, we defined a "dominant" emission age for BB and anthropogenic emissions as the time (prior to observation and expressed in days) when the total $\mathrm{CO}_{\text {fire }}$ and $\mathrm{CO}_{\text {ant }}$ contributions reached $75 \%$ of their 20-day integrated value. Alternatively, emission age was also estimated by identifying the time when $\mathrm{CO}$ showed the maximum increase along the backward Lagrangian simulation. However, since no substantial differences were observed, only the first method is used in this paper. $\mathrm{O}_{3}, \mathrm{CO}$ and $\mathrm{BC}$ ICO-OV observations are averaged over 3-h to compare directly to FLEXPART data.

\section{Results}

\subsection{Atmospheric tracer annual cycles at ICO-OV}

\subsubsection{Carbon monoxide (CO)}

Figure 1 reports the annual cycle of CO. During 2007-2009, the average $\mathrm{CO}$ at ICO-OV was $122 \pm 7 \mathrm{ppb}$ (in terms of mean \pm expanded uncertainty) at a confidence level of $95 \%$. The annual $\mathrm{CO}$ cycles were characterised by the highest monthly values from February to April and minima from June to September (only months with data coverage larger than 15 days have been reported). Increasing $\mathrm{CO}$ is observed during autumn. Not-negligible inter-annual variability characterised CO levels at ICO-OV. In particular, high CO was observed during spring and autumn 2007 with mixing ratios exceeding by $20 \mathrm{ppb}$ the average values during 20082009 . Both in term of annual shape and temporal variability, the CO seasonal cycles at ICO-OV are well comparable 

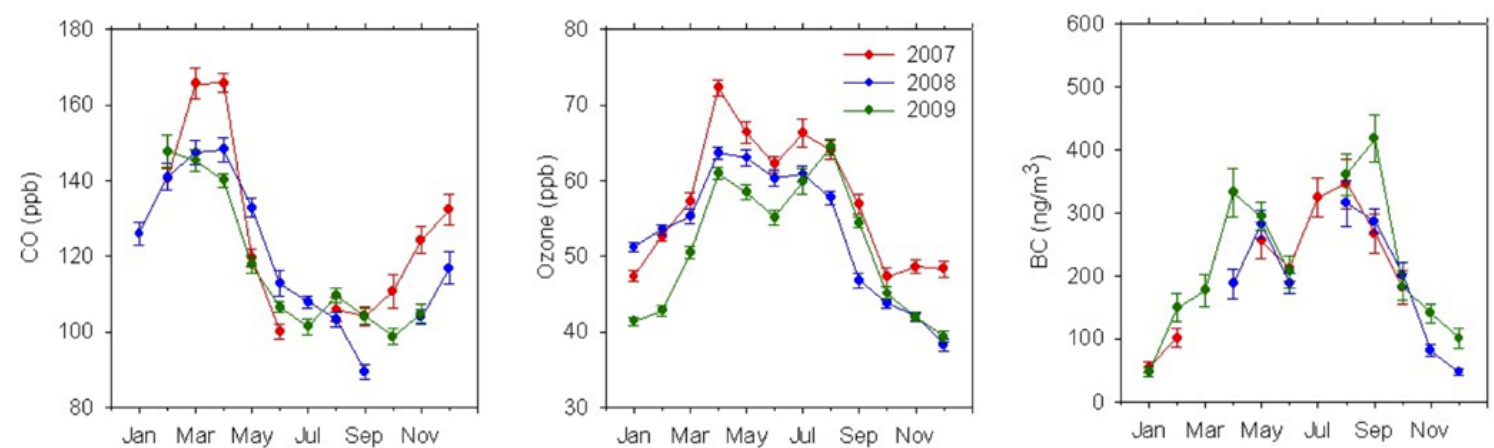

Fig. 1. Monthly means of $\mathrm{CO}, \mathrm{O}_{3}$ and $\mathrm{BC}$ at ICO-OV for the years 2007, 2008 and 2009. The error bars denote the average expanded uncertainties with $p<95 \%$.

with those at other high-altitude mountain sites in Europe (Zelwegger et al., 2009; Gilge et al., 2010). The observed annual cycle results from varying contributions by natural and anthropogenic emissions, production vs. removal processes and atmospheric transport (e.g. Yurganov et al., 1999; Chevalier et al., 2008; Gilge et al., 2010). In particular, the slower chemical destruction leads to a longer CO lifetime in winter and subsequent accumulation, thus explaining the observed late winter/early spring peak. Long-range transport can play a significant role in determining the seasonal cycle: in fact, as pointed out by Pfister et al. (2006), Asian and North American anthropogenic CO sources can significantly impact tropospheric Europe between January and March in addition to continental emissions. Another possible contribution that will be explored later comes from BB emissions that strongly impact $\mathrm{CO}$ variability during specific episodes (e.g. Yurganov et al., 2005; Cristofanelli et al., 2009; Zellweger et al., 2009).

\subsubsection{Surface ozone $\left(\mathrm{O}_{3}\right)$}

The simultaneously observed average $\mathrm{O}_{3}$ for the years 20072009 at ICO-OV was $54 \pm 3$ ppb, in good agreement with earlier measurements (Cristofanelli et al., 2006). As reported by Fig. 1, the annual $\mathrm{O}_{3}$ cycle is characterised by a winter minimum and two peaks: (1) in spring (in April, for the three years here considered) and (2) in summer (from July to August). This is a common feature for high-altitude measurement sites in Europe (e.g. Chevalier et al., 2007; Gilge et al., 2010). The summer peak is usually explained by increased photochemical production of $\mathrm{O}_{3}$ in the lower troposphere: summer fair and warm weather conditions contribute to direct $\mathrm{O}_{3}$ production from anthropogenic precursors and favour the export of polluted air masses from the boundary layer to the free troposphere of continental Europe (Henne et al, 2005; Cristofanelli et al., 2007). At middle latitudes in the Northern Hemisphere, the spring $\mathrm{O}_{3}$ maximum can be related to the accumulation of precursors (as seen at ICO-OV for $\mathrm{CO}$ ) during winter and subsequent $\mathrm{O}_{3}$ production (Monks, 2000; Virganzan, 2004). Stratosphere-to- troposphere transport (STT) might also increase $\mathrm{O}_{3}$ at ICOOV during spring (Stohl et al., 2000), even if more recent analyses (Cristofanelli et al., 2006) also indicate high STT influence during autumn and winter.

\subsubsection{Equivalent black carbon (BC)}

The average monthly $\mathrm{BC}$ concentration during the year 2007-2009 was $213 \pm 34 \mathrm{ng} \mathrm{m}^{-3}$. This value is comparable with typical average levels recorded at European continental background sites (Van Dingenen et al., 2005; Putaud et al., 2004). Similarly to $\mathrm{O}_{3}$ (Fig. 1), the annual cycle is characterised by the presence of a winter minimum (DecemberJanuary) and maxima in spring (April-May) and late summer (August-September). This behaviour probably reflects the higher efficiency of uplift during warmer months and the subsequent transport of polluted air masses from the boundary layer to the measurement site (Marinoni et al., 2008; Cristofanelli et al., 2007). Interestingly, a secondary minimum in BC was observed during June when wet deposition is expected to peak at $\mathrm{CMN}$, due to maximum rainfall. Large variability characterises the BC annual cycle with monthly values spanning almost an order of magnitude from $50 \mathrm{ng} \mathrm{m}^{-3}$ to $400 \mathrm{ng} \mathrm{m}^{-3}$.

\section{Role of biomass burning}

The identification of $\mathrm{BB}$ events at ICO-OV is done here based on a combination of observation and model analysis.

The first step is to quantify the monthly mean contribution of $\mathrm{CO}_{\text {fire }}$ at ICO-OV to provide an estimate of the mean impact and its seasonal variability. Figure 2 shows that FLEXPART $\mathrm{CO}_{\text {fire }}$ was low for the most part of the investigation period with an annual average value of $2.5 \mathrm{ppb}$. It contributed only up to $2.6 \%$ to the mean $\mathrm{CO}$ observed at ICO-OV during 2007-2009. Only few events (about $3 \%$ of the entire dataset) were characterised by $\mathrm{CO}_{\text {fire }}$ exceeding $10 \mathrm{ppb}$ and the

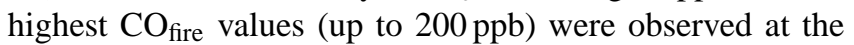
end of August 2007 when a strong BB plume was detected 


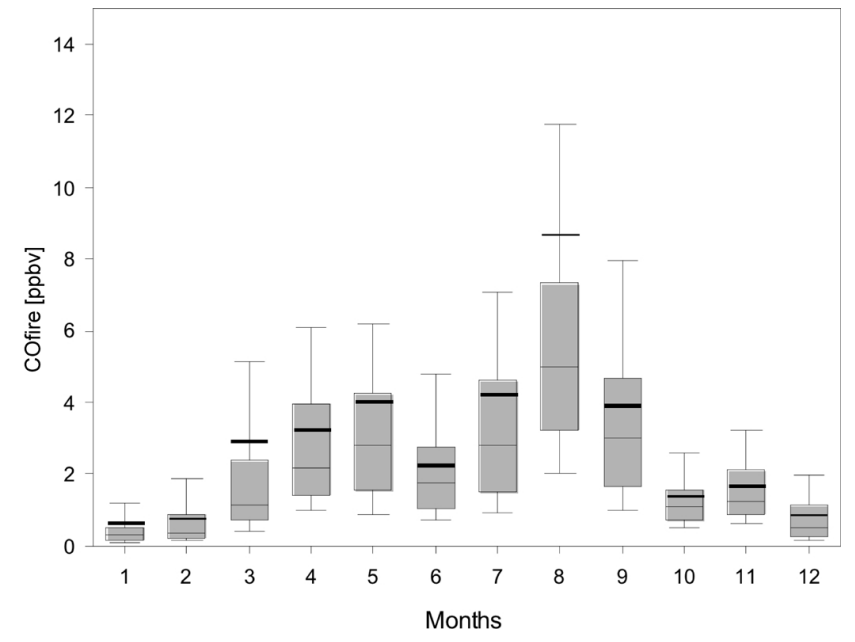

Fig. 2. Monthly distributions of FLEXPART $\mathrm{CO}_{\text {fire }}$ at ICO-OV during the period January 2007-July 2009. The boxes and whisker denote the 10, 25, 50, 75 and 90 percentiles. Bold lines represent average values.

at ICO-OV (see Cristofanelli et al., 2009). The $\mathrm{CO}_{\text {fire }}$ contribution shows a clear annual cycle with the highest values during the warm months: maximum monthly average values were observed in July/September (4.2 and $3.6 \mathrm{ppb}$, respectively) and August (8.6 ppb) and a secondary maximum in late spring ( $4.0 \mathrm{ppb}$ in May). As deduced by the increase in the lowest percentiles of the monthly distributions (Fig. 2), these higher values were due both to an increase of the $\mathrm{CO}_{\text {fire }}$ baseline value and to the occurrence of specific events, as testified by the large upper percentiles.

To identify at ICO-OV the presence of BB plumes, we considered the time periods for which FLEXPART $\mathrm{CO}_{\text {fire }}$ continuously exceeded $10 \mathrm{ppb}$ for more than $12 \mathrm{~h}$. Figure 3 reports $\mathrm{CO}$ observed at ICO-OV (black points) together with calculated FLEXPART $\mathrm{CO}_{\text {fire }}$ (red line): time periods for which the selection criterion is fulfilled are highlighted with coloured dots, scaled on the fire emission age deduced by FLEXPART outputs. Following FLEXPART, $\mathrm{CO}_{\text {fire }}$ enhancements occur sporadically and for a limited period of time. By considering only the period with $\mathrm{CO}_{\text {fire }}$ exceeding $10 \mathrm{ppb}, 16$ events with a duration ranging from 12 to $72 \mathrm{~h}$ were identified, for a total of 21 days over the three years. Based on the FLEXPART analyses, for these events the transport of BB emissions occurs at very different scales: six events originated from the SE/MB region, two events from the Balkan peninsula, one event from Russia. Long range transport may have a likely role with 5 events from North America, one from Central America and one from equatorial Africa. The majority of BB events (11) occurred from May to September, thus confirming that transport of BB emissions mostly occurred during warm months. Over the 16 events detected by FLEXPART outputs, those having "local" BB source were characterized for the greatest part ( $6 / 8$ events) by clear $\mathrm{CO}$ enhancements $(\Delta \mathrm{CO}>0 \mathrm{ppb})$ in respect to the average behaviour obtained by applying the 21-day running mean, those having "global" sources were characterized by negative or non-significant $\Delta \mathrm{CO}(7 / 7)$ and the only event that was attributed to emission occurring at "regional" scale showed a positive $\triangle \mathrm{CO}$.

In this paper, we decided to describe in greater detail five "representative" events (24-25 April 2007, 28 August1 September 2007; 23-24 March 2009; 28 March-1 April 2009, 1-4 May 2009), that might resume the main features of the 16 events we detected by the FLEXPART analysis. In particular, according to FLEXPART, these events are due to: (i) local transport of BB emissions from central Alps (event I) and north Africa, south Italy and Greece (event II), (ii) regional transport from Russia (event V), (iii) global scale transport from North America (event III) and west equatorial Africa (event IV). Supplement presents the $\mathrm{CO}_{\text {fire }}$ source contributions maps for each of these events (Figs. S1-S5), while Table 1 reports the $\mathrm{CO}, \mathrm{O}_{3}$ and $\mathrm{BC}$ : $\mathrm{CO}_{\text {fire }}$ contributions ranged from 10.1 to $47.5 \%$ of the observed $\mathrm{CO}$ mixing ratio. Events I, II and $\mathrm{V}$ are characterized by clear $\mathrm{CO}$ enhancements $(\triangle \mathrm{CO}>0 \mathrm{ppb})$ with respect to the average behaviour obtained by applying the 21-day running mean. Events III and IV, related with long range transport of $\mathrm{BB}$ emissions, were instead characterised by $\mathrm{CO}$ decreases $(\triangle \mathrm{CO}<0 \mathrm{ppb})$. The actual $\mathrm{CO}$ due to a more aged and distant BB may be highly variable due to a combination of processes that is difficult to evaluate and that may lead to the negative observed $\mathrm{CO}$ anomaly. FLEXPART showed to be accurate in capturing long-range transport, including BB plume (e.g. Stohl et al., 1998, 2006, 2007; Forster et al., 2001; Damoah et al., 2006; Lapina et al., 2008). However, the simulated transport can be inaccurate for individual cases and it is therefore important to use additional data to confirm a long-range transport episode. For these reasons, we performed some additional analysis to have a qualitative assessment on the reliability of the FLEXPART analysis for these BB long range transport events. As shown by Fig. 3b, event III is characterized by an increase of CO up to $170 \mathrm{ppb}$. Nevertheless, due to the relatively high $\mathrm{CO}$ values occurring before and after the event, $\triangle \mathrm{CO}$ was negative. Event IV is also characterized by $\mathrm{CO}$ up to $160 \mathrm{ppb}$. However a further enhancement in $\mathrm{CO}$ occurred $24 \mathrm{~h}$ after the possible arrival of the BB plume. Even if possible error in the timing of the plume arrival at $\mathrm{CMN}$ cannot be ruled out, nevertheless no clear $\mathrm{BB}$ signature can be seen in $\mathrm{O}_{3}$ and $\mathrm{BC}$ data for this latter CO increase (not shown). It is not possible to disentangle the role of uncertainty in air parcel position and timing related with transport simulation, that may induce an erroneous attribution, and the limits in detectability of the event from observations, due to a highly variable background that may hide the $\mathrm{CO}$ increase related with $\mathrm{BB}$ emissions. Nevertheless, even if it is difficult to provide a definitive attribution of those events, the arguments supporting a realistic impact of $\mathrm{BB}$ emissions for these two events are (1) the 

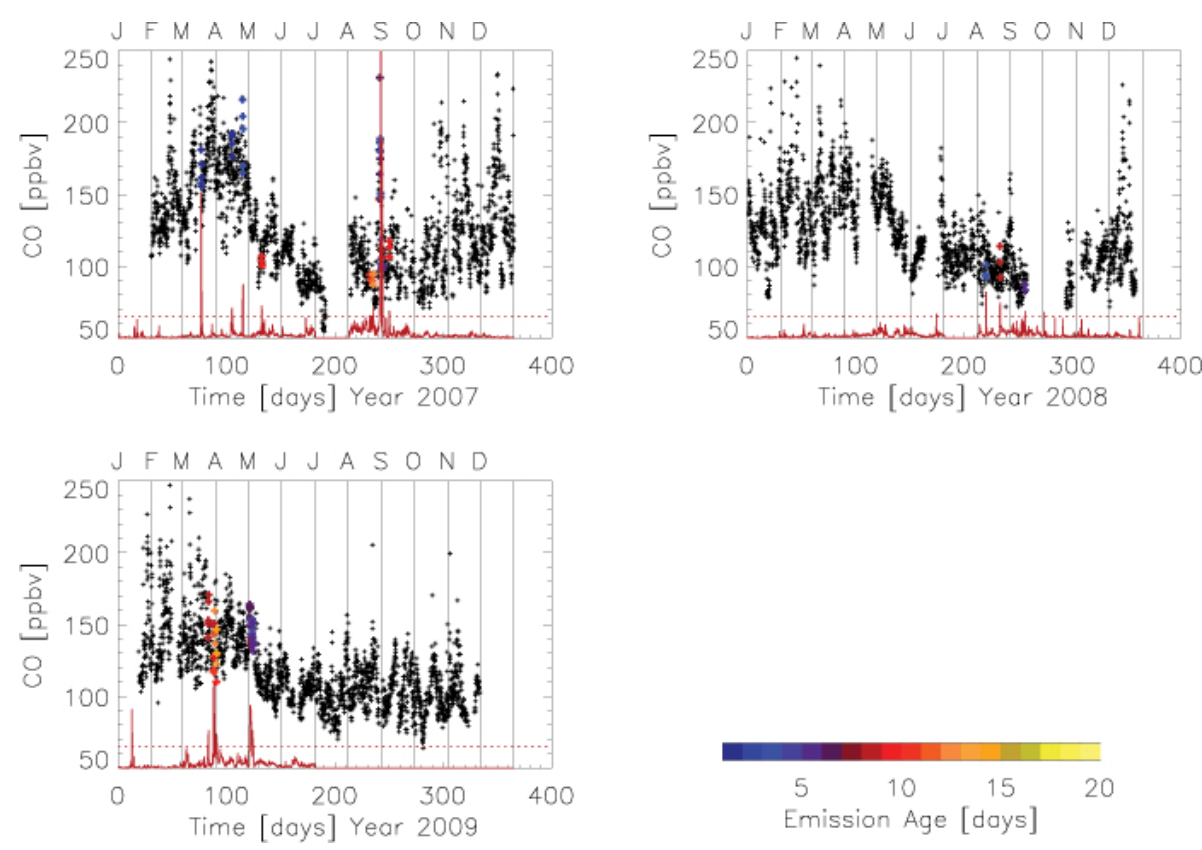

Fig. 3a. Time series of observed CO at ICO-OV (black dots) with FLEXPART CO fire (red line). Observations at ICO-OV are tagged with the FLEXPART fire emission age (colour scale) when FLEXPART fire CO exceeded $10 \mathrm{ppb}$. FLEXPART CO fire $_{\text {is }}$ plotted with a positive constant bias of $50 \mathrm{ppb}$ to reduce the extent of $\mathrm{y}$-axis.
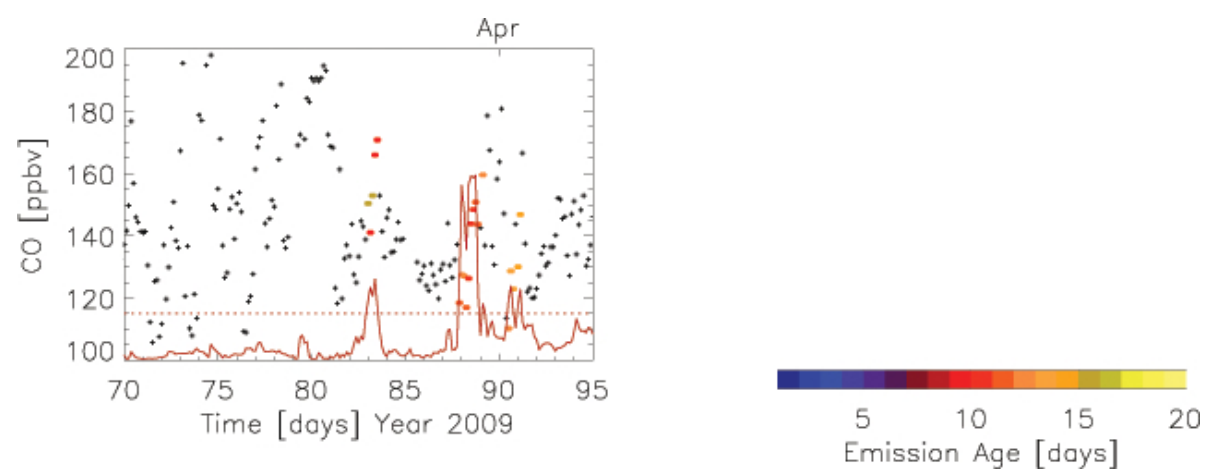

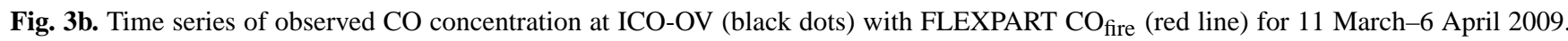
Observations at ICO-OV are tagged with the FLEXPART fire emission age (colour scale). FLEXPART CO is plotted with a positive bias of $50 \mathrm{ppb}$ to reduce the extent of $\mathrm{y}$-axis.

compactness of the FLEXPART retroplume that indicates a persistent and robust transport pattern; (2) the biomass burning emission based on fire observations, further supported by satellite CO observations (MOPITT instrument on board of on NASA's EOS Terra spacecraft) showing enhanced CO in the BB source regions identified by FLEXPART (not shown here). Moreover, Real et al. (2007) showed that the mixing ratio of $\mathrm{CO}$ in forest fire plumes decreases by $50 \%$ during a 5-day transport due to atmospheric mixing. Additionally, for the event IV, injection of BB emissions into tropical air masses with low pre-existing $\mathrm{CO}$ mixing ratios may lead to $\mathrm{CO}$ values still lower than those typically observed in the middle latitudes (WMO, 2011). Thus, the advection of this plume can lead to a decrease of observed $\mathrm{CO}$ at ICO-OV, even in the presence of a substantial BB contribution. This could partially explain the significant negative correlation existing between the FLEXPART $\mathrm{CO}_{\text {fire }}$ and the $\mathrm{CO}$ mixing ratio observed at ICO-OV during the episode IV (see Table 1).

$\mathrm{O}_{3}$ has a large variability among the identified fire plumes, with mean mixing ratios ranging from 45.2 to $88.5 \mathrm{ppb}$ : overall, $4 / 5$ events show $\mathrm{O}_{3}$ enhancement from the 21-day filtered time series $\left(\Delta \mathrm{O}_{3}>0 \mathrm{ppb}\right)$. Figure $4 \mathrm{a}$ shows the relationship between $\mathrm{CO}$ and $\mathrm{O}_{3}$ mixing ratios observed at ICO-OV during the five events. In order to remove the correlation due to the diurnal cycle of $\mathrm{CO}$ and $\mathrm{O}_{3}$ at ICO-OV (see e.g. Cristofanelli et al., 2009), here we considered the residuals of 3-h 
Table 1. List of the five "representative" BB events at ICO-OV as deduced by FLEXPART analyses. For each event we reported: start and end dates ("Date"), transport-scale ("Scale"), the emission region ("Origin"), the range (minimum, mean and maximum values) of representative emission ages during the event ("Emission age"), the averaged fraction of FLEXPART CO fire contribution ("CO fire fraction"), the linear correlation coefficient between $\Delta \mathrm{CO}$ and $\mathrm{CO}_{\text {fire }}$ (" $R$ "), the mean $\mathrm{CO}$ and $\Delta \mathrm{CO}$ at ICO-OV ("Mean $\mathrm{CO}$ "; "Mean $\Delta \mathrm{CO}$ "), the mean $\mathrm{O}_{3}$ and $\Delta \mathrm{O}_{3}$ at ICO-OV ("Mean $\mathrm{O}_{3}$ "; "Mean $\mathrm{O}_{3}$ "), the mean BC and $\triangle \mathrm{BC}$ at ICO-OV ("Mean BC"; "Mean BC"), the calculated $\mathrm{O}_{3}-\mathrm{CO}$ and BC-CO enhancement ratios ("O ${ }_{3}-\mathrm{CO}$ ER"; "BC-CO ER").

\begin{tabular}{|c|c|c|c|c|c|c|c|c|c|c|c|c|c|c|c|}
\hline Event & Date & Scale & Origin & $\begin{array}{l}\text { Time } \\
\text { length } \\
\text { (h) }\end{array}$ & $\begin{array}{l}\text { Emission age } \\
\text { Min - Avg - Max } \\
\text { (h) }\end{array}$ & $\begin{array}{l}\mathrm{CO}_{\text {fire }} \\
\text { fraction } \\
(\%)\end{array}$ & $\begin{array}{l}R \\
\Delta \mathrm{CO}- \\
\mathrm{CO}_{\text {fire }}\end{array}$ & $\begin{array}{l}\text { Mean } \\
\text { CO } \\
(\mathrm{ppb})\end{array}$ & $\begin{array}{l}\text { Mean } \\
\Delta \mathrm{CO} \\
(\mathrm{ppb})\end{array}$ & $\begin{array}{l}\text { Mean } \\
\mathrm{O}_{3} \\
(\mathrm{ppb})\end{array}$ & $\begin{array}{l}\text { Mean } \\
\Delta \mathrm{O}_{3} \\
(\mathrm{ppb})\end{array}$ & $\begin{array}{l}\text { Mean } \\
\mathrm{BC} \\
\left(\mathrm{ng} \mathrm{m}^{-3}\right)\end{array}$ & $\begin{array}{l}\text { Mean } \\
\Delta \mathrm{BC} \\
\left(\mathrm{ng} \mathrm{m}^{-3}\right)\end{array}$ & $\begin{array}{l}\mathrm{O}_{3}- \\
\mathrm{CO} \\
\mathrm{ER}\end{array}$ & $\begin{array}{l}\mathrm{BC}- \\
\mathrm{CO} \\
\mathrm{ER}\end{array}$ \\
\hline I & $\begin{array}{l}24-25 \\
\text { Apr } 2007\end{array}$ & Local & $\begin{array}{l}\text { MB/SE } \\
\text { (Alps) }\end{array}$ & 19 & $72-72-72$ & 13.3 & 0.17 & 196.1 & 40.9 & 88.5 & 14.9 & 1072.3 & 653.4 & 0.27 & 9.83 \\
\hline II & $\begin{array}{l}28 \text { Aug- } \\
1 \text { Sep } \\
2007\end{array}$ & Local & $\begin{array}{l}\text { MB/SE } \\
\text { (North } \\
\text { Africa) }\end{array}$ & 79 & $48-100-144$ & 47.5 & 0.38 & 150.5 & 44.9 & 67.7 & 9.1 & 754.3 & 413.4 & 0.26 & 11.50 \\
\hline III & $\begin{array}{l}23-24 \\
\text { Mar } 2009\end{array}$ & Global & $\begin{array}{l}\text { North } \\
\text { America }\end{array}$ & 16 & $192-196-216$ & 14.5 & 0.41 & 139.2 & -5.0 & 54.5 & 3.1 & 278.4 & 45.4 & $\mathrm{n} / \mathrm{d}$ & 14.99 \\
\hline IV & $\begin{array}{l}28 \mathrm{Mar}- \\
1 \mathrm{Apr} \\
2009\end{array}$ & Global & $\begin{array}{l}\text { Equatorial } \\
\text { Africa }\end{array}$ & 82 & $192-239-288$ & 23.6 & -0.45 & 136.4 & -6.9 & 45.2 & -7.8 & 44.1 & -223.8 & -0.22 & 2.69 \\
\hline V & $\begin{array}{l}\text { 1-4 May } \\
2009\end{array}$ & Regional & Russia & 91 & $96-126-168$ & 17.9 & 0.68 & 151.4 & 19.9 & 66.5 & 5.1 & 569.0 & 276.7 & 0.71 & 29.83 \\
\hline
\end{tabular}

averaged $\left(\mathrm{CO}^{\text {res }}, \mathrm{O}_{3}^{\text {res }}, \mathrm{BC}^{\text {res }}\right)$ with respect to the mean diurnal variation estimated in the 21 days around the $\mathrm{BB}$ event. The different scatter of data among the detected events (with $\mathrm{R}$ values ranging from -0.14 for the event III to 0.93 for the event $\mathrm{I}$ ) is indicative of a great variability of chemical reactivity in air-masses potentially impacted by BB.

Previous studies (see Val Martin et al., 2006 and references therein) showed that the slope of the linear fit of $\mathrm{O}_{3}$ versus $\mathrm{CO}$ can be used to evaluate the $\mathrm{O}_{3} / \mathrm{CO}$ enhancement ratio (ER), i.e about the amount of $\mathrm{O}_{3}$ molecule produced per $\mathrm{CO}$ molecule emitted. We calculated the linear fit by applying the reduced major axis (RMA) technique to four events characterised by $\mathrm{O}_{3}-\mathrm{CO}$ linear correlation coefficients larger than 0.30 (see Table 1). The range of the positive $\mathrm{O}_{3} / \mathrm{CO}$ ER $(0.27-0.71)$ was in relatively good agreement with previous characterization of BB plumes. Val Martin et al. (2006) reported ER ranging from 0.14 to 0.89 in boreal fire plumes observed at the Azores Islands, while Bertschi and Jaffe (2005) found ER from 0.15 to 0.84 in plumes from Asian boreal wildfires over Northwest US, suggesting that significant $\mathrm{O}_{3}$ production can occur in $\mathrm{BB}$ plumes probably due to the slow recycling of $\mathrm{PAN}, \mathrm{HNO}_{3}$ and organic nitrates (Honrath et al., 2004; Bertschi and Jaffe, 2005). A negative value of 0.22 is observed during event IV. Negative or not-significant $\mathrm{O}_{3} / \mathrm{CO}$ ER have been already observed in aged BB plumes by Val Martin et al. (2006) and Real et al. (2007). This was attributed to the high aerosol concentrations within fire emission plumes or other processes affecting night-time chemistry (i.e. hydrolysis of $\mathrm{N}_{2} \mathrm{O}_{5}$ ) as well as $\mathrm{O}_{3}$ loss by reaction with organic compounds during long-range transport. Real et al. (2006) showed that the strong aerosol light extinction in dense $\mathrm{BB}$ smoke plumes can decrease $\mathrm{O}_{3}$ formation efficiency. In our case, a strong Saharan dust transport event was also detected at ICO-OV by in-situ and satellite
(MODIS) observations. This could possibly lead to heterogeneous removal of $\mathrm{O}_{3}$ and its precursors (via $\mathrm{HNO}_{3}$ and $\mathrm{NO}_{3}$ depletion) and by decreasing photolysis rate (e.g. He and Carmichel, 1999; Balis et al., 2000; Harrison et al., 2001). Depletion of $\mathrm{O}_{3}$ in Saharan dust layers was systematically observed at ICO-OV by Bonasoni et al. (2004).

$\mathrm{BC}$ concentrations are highly variable during the events, ranging from 44.1 to $1072.3 \mathrm{ng} \mathrm{m}^{-3}$ (Table 1). BC concentrations showed positive anomalies with respect to the 21 days average for events I, II, III and V and negative for event IV which was characterised by the lowest BC concentrations indicating that removal processes may have been important. $\mathrm{BC}^{\text {res }}$ as a function of $\mathrm{CO}^{\text {res }}$ is reported in Fig. $4 \mathrm{~b}$ and all the analysed events show significant positive correlation; the linear correlation coefficient $R$ ranges from 0.31 (event IV) to 0.94 (event II). The $\mathrm{BC}^{\text {res }} / \mathrm{CO}^{\text {res }}$ slopes were very similar, except for event IV. RMA analysis gives BC/CO ERs value ranging from 2.69 to 29.83 (Table 1). Previous observations of BB (from North America and Siberia) at baseline stations in the Azores (Val Martin et al., 2006), Ireland (Forster at al., 2001) an Japan (Kaneyasu et al., 2007) reported $\mathrm{BC} / \mathrm{CO}$ ERs ranging from 0.5 to 8.4. Warneke et al. (2009) and Kondo et al. (2011) reported ERs of 8.5 \pm 5.4 and $10 \pm 5 \mathrm{ng} \mathrm{m}^{-3} \mathrm{ppbv}^{-1}$ for BB in Asia (Sibera and Kazakhstan). Pan et al. (2011), reported BC/CO ratio of $10.3 \pm 0.3$ and $11.6 \pm 0.5 \mathrm{ng} \mathrm{m}^{-3} \mathrm{ppb}^{-1}$ for BB plumes observed at the background station Mt. Huang (1840 m a.s.1.) in east China. Thus, while events I, II and IV showed ERs in good agreement with already published values, events III and V were characterised by significant higher values. It is not entirely clear why the BC-CO slopes were so large, but different explanations could be considered, especially for event $\mathrm{V}$. Firstly, these high BC/CO ERs may be explained by high combustion efficiency of the source fires (e.g. Kondo et al., 

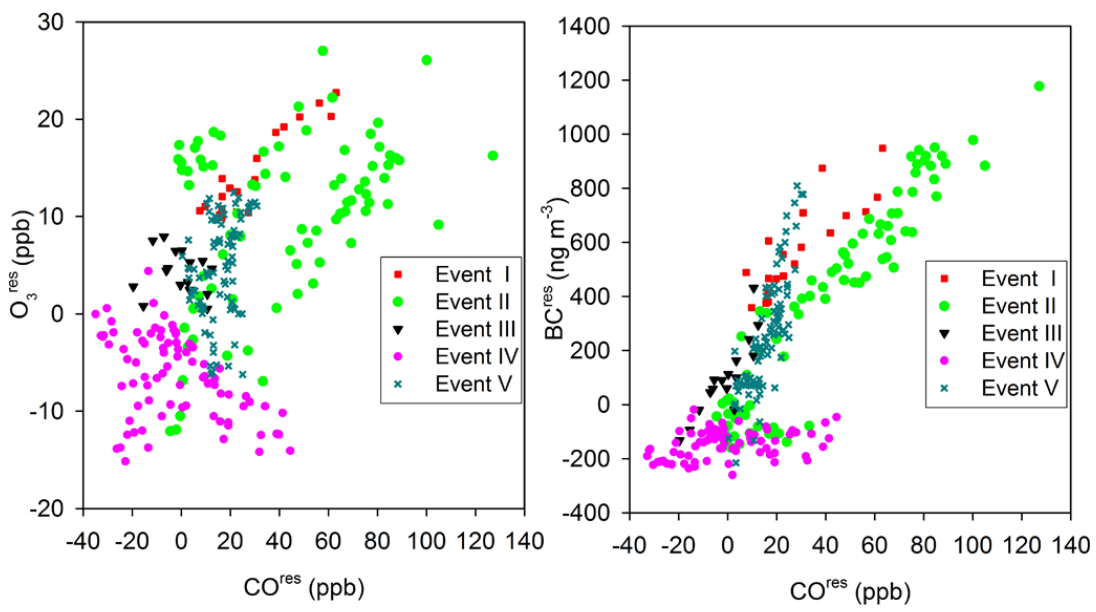

Fig. 4. Relationship between observed $\mathrm{CO}^{\text {res }}, \mathrm{O}_{3}^{\text {res }}$ and $\mathrm{BC}^{\text {res }}$ during the five representative $\mathrm{BB}$ events listed in Table 1 .

2011). Secondly, Pan et al. (2011) showed that BC/CO ERs are strongly influenced by rain washout and/or large environmental RH along the transport pathways. In particular, dry conditions dominated at ICO-OV during event V, with RH values well below $60 \%$. Moreover, as deduced by the analysis of meteorological analyses based on the Global Data Assimilation System (GDAS) by the National Centre for Environmental Prediction (NCEP), also along the transport path, dry conditions prevailed for this event (average $\mathrm{RH}$ values: $59 \%$ ), suggesting that rain washout or removal processes in high RH environment were unlikely for this specific event. Finally, it cannot be completely excluded anthropogenic contribution within $\mathrm{BB}$ plumes, which can increase the slope of the BC-CO correlation. As reported by Cristofanelli et al. (2009), at ICO-OV, anthropogenic pollution plumes from the polluted Po basin can be characterised by ERs higher than $14 \mathrm{ng} \mathrm{m}^{-3} \mathrm{ppb}^{-1}$. FLEXPART retroplume analyses (here not shown) indicated significant footprint emission sensitivity over the central/northern France and the eastern Po basin for the air-masses reaching ICO-OV during event III and V, respectively. Thus, it is possible that mixing with polluted airmasses occurred 1-2 days before the arriving of air-masses at the measurement site.

To provide a more robust characterization of the $\mathrm{O}_{3} / \mathrm{CO}$ and $\mathrm{BC} / \mathrm{CO} \mathrm{ER}$ as a function of the $\mathrm{BB}$ plume ages, we considered the $16 \mathrm{BB}$ events identified by FLEXPART (Fig. 5). By excluding event IV (as discussed before) and a further very old $\mathrm{BB}$ event (representative emission age: $273 \mathrm{~h}$ ), we observed for $\mathrm{O}_{3}$ a good qualitative agreement with previous investigations showing a general increase of ER values with the ageing of BB plumes (e.g. Pfister et al., 2006; Val Martin et al., 2006; Real et al., 2007; Cristofanelli et al, 2009), probably indicating the role of PAN, $\mathrm{HNO}_{3}$ and organic nitrates, which favor the photochemical formation of $\mathrm{O}_{3}$. On the other side a general decrease of ERs with increasing emission age has been observed for $\mathrm{BC}$, possibly related to a more effi-

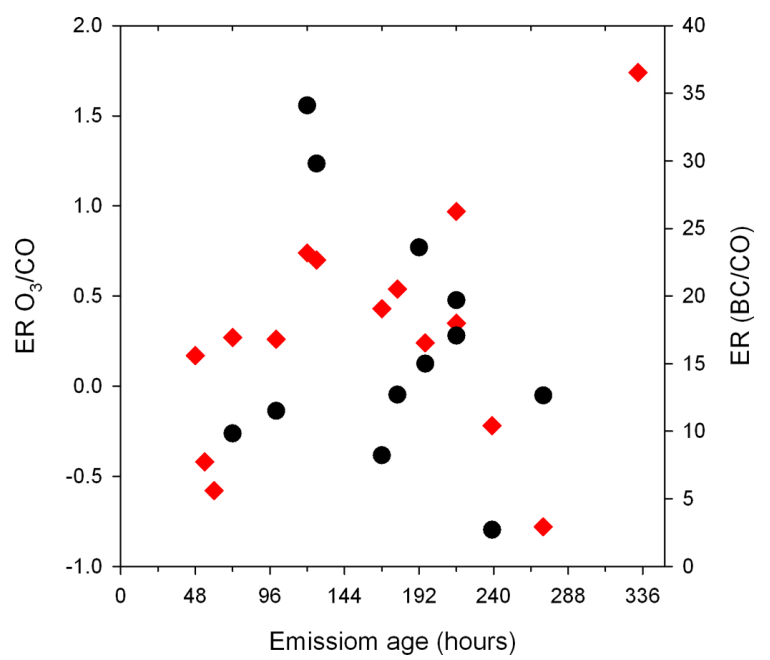

Fig. 5. ERs of $\mathrm{O}_{3}$ (red) and $\mathrm{BC}$ (black) relative to $\mathrm{CO}$ observed for the $16 \mathrm{BB}$ events detected at CMN by FLEXPART.

cient scavenging of aerosol particles during long atmospheric transport. On the other side we did not obtain a clear relationship between the type of vegetation burnt or the different source regions with the ERs. This could indicate that the plume aging is the main parameters for determining ERs in relatively aged (i.e. older than 2 days) BB plumes. However, a number of uncertainties related with the actual type of combustion (e.g. smoldering vs. flaming), actual composition of the fuel, its moisture and structure (see Andrea and Merlet, 2001) can affect our results.

\section{Role of anthropogenic emissions}

We turn now to the role of anthropogenic emissions in affecting atmospheric composition at ICO-OV based on the observations of $\Delta \mathrm{O}_{3}, \Delta \mathrm{CO}$, and $\mathrm{BC}$ and on the $\mathrm{CO}_{\text {ant }}$ calculated 

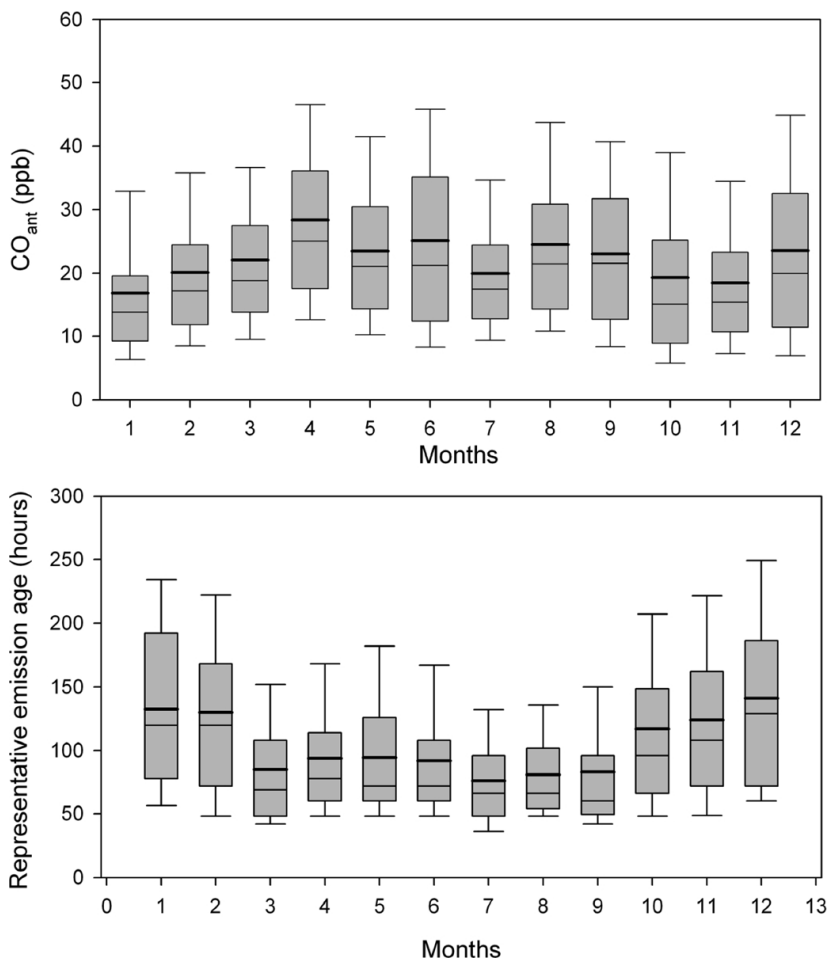

Fig. 6. Monthly distributions of FLEXPART daily $\mathrm{CO}_{\text {ant }}$ (upper plot) with related representative emission ages (bottom plot) at ICOOV during the period January 2007-July 2009. The boxes and whiskers denote the 10th, 25th, 50th, 75th and 90th percentiles. Bold lines represent average value. Data at 3-h resolution have been shown.

by FLEXPART. The 20-day old FLEXPART $\mathrm{CO}_{\text {ant }}$ has an average value of $22.4 \mathrm{ppb}$, which corresponds to $17.4 \%$ of the mean $\mathrm{CO}$ value observed at ICO-OV during the same period. It is difficult to recognise a clear yearly cycle of $\mathrm{CO}_{\text {ant }}$ (Fig. 6): the highest monthly $\mathrm{CO}_{\text {ant }}$ is found for April (27.7 ppb) and the lowest ones in autumn and early winter (January $16.8 \mathrm{ppb}$, October $19.3 \mathrm{ppb}$ and November $18.5 \mathrm{ppb})$. In particular, April 2007 was characterised by higher average $\mathrm{CO}_{\text {ant }}(+25 \%)$ than April 2008 and 2009, in good agreement with the highest observed $\mathrm{CO}$ at ICO-OV (see Fig. 1). This suggests that the transport variability of anthropogenic CO simulated by FLEXPART can explain part of the inter-annual $\mathrm{CO}$ variability observed at ICO-OV.

Larger upper percentiles of FLEXPART $\mathrm{CO}_{\text {ant }}$ indicate that spring and summer (from April to September) are more affected by episodes with air-masses rich in anthropogenic $\mathrm{CO}$. These events are typically due to relatively fresh emissions. The emission age median value for April-September is only $72 \mathrm{~h}$, whereas it is $114 \mathrm{~h}$ from October to February. This can be explained by the more efficient export of $\mathrm{CO}$ from the planetary boundary layer to the altitude of ICO$\mathrm{OV}$ during summer. FLEXPART also gives high $\mathrm{CO}_{\text {ant }}$ in December with upper quantiles similar to those seen for the

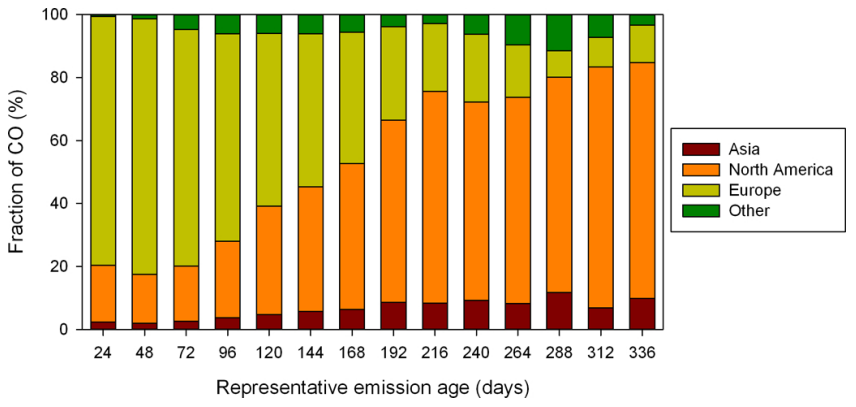

Fig. 7. Fraction of $\mathrm{CO}_{\mathrm{ant}}$ at $\mathrm{CMN}$ (y-axis) as a function of source regions (stacked coloured bars) and representative emission age (x-axis).

warm months. However, the median emission age $(129 \mathrm{~h})$ is much higher than in summer. Even if a significant fraction of these high $\mathrm{CO}_{\text {ant }}$ were still related with moderately aged (less than $96 \mathrm{~h}$ ) European emissions, transport from North America significantly increased the emission age at ICO-OV during specific periods (e.g. 3-11 December 2008). This is in agreement with previous work showing that inter-continental transport can be a relevant source of polluted air-masses over Europe (e.g. Stohl and Trickl, 1999; Trickl et al., 2003).

With the aim of systematically investigate the source regions of $\mathrm{CO}_{\text {ant }}$ as a function of the representative emission ages, we calculated the average contribution to the total $\mathrm{CO}_{\text {ant }}$ at Mt. Cimone for different source regions tagged back by FLEXPART (i.e. Europe, Asia, North America and other continents). This analysis (see Fig. 7) suggests that the contributions related to the long-range transport from outside Europe became predominant for emission ages larger than $120 \mathrm{~h}$. In particular, anthropogenic emissions from North America appeared to play a predominant role when the $\mathrm{CO}_{\mathrm{ant}}$ emission age exceeded $192 \mathrm{~h}$. For emission ages older than 120 days not negligible contributions were also tagged to emissions from Asia (ranging from 4.7 to $11.7 \%$, as a function of emission age) as well as from other continents (ranging from 3.9 to $11.5 \%$ ), with predominant contribution related with transport of anthropogenic emission from Africa.

Figure 8 reports the observed anomalies of $\mathrm{CO}, \mathrm{O}_{3}$ for three seasons corresponding to the yearly observed $\mathrm{CO}$ maximum (January-April), minimum (May-September) and transition period (October-December) for the 30-month investigation period. $\triangle \mathrm{CO}$ and $\Delta \mathrm{O}_{3}$ have been reported as a function of observed $\mathrm{BC}$ concentrations and $\mathrm{CO}_{\text {ant }}$ emission age (coloured scales). In order to reduce the effect of diurnal variations caused by thermal circulations and local photochemistry, data have been averaged over a $12 \mathrm{~h}$ period centred around 00:00 and 12:00 UTC +1 . Correlation between $\Delta \mathrm{CO}$ and $\Delta \mathrm{O}_{3}$ is strong and positive in May-September ( $R: 0.79$ ), indicating photochemical $\mathrm{O}_{3}$ formation. In particular, enhanced $\Delta \mathrm{CO}$ and $\Delta \mathrm{O}_{3}$ are observed with the presence of high BC concentration $\left(>400 \mathrm{ng} \mathrm{m}^{-3}\right)$. This indicates that polluted air-masses influenced by combustion emissions 

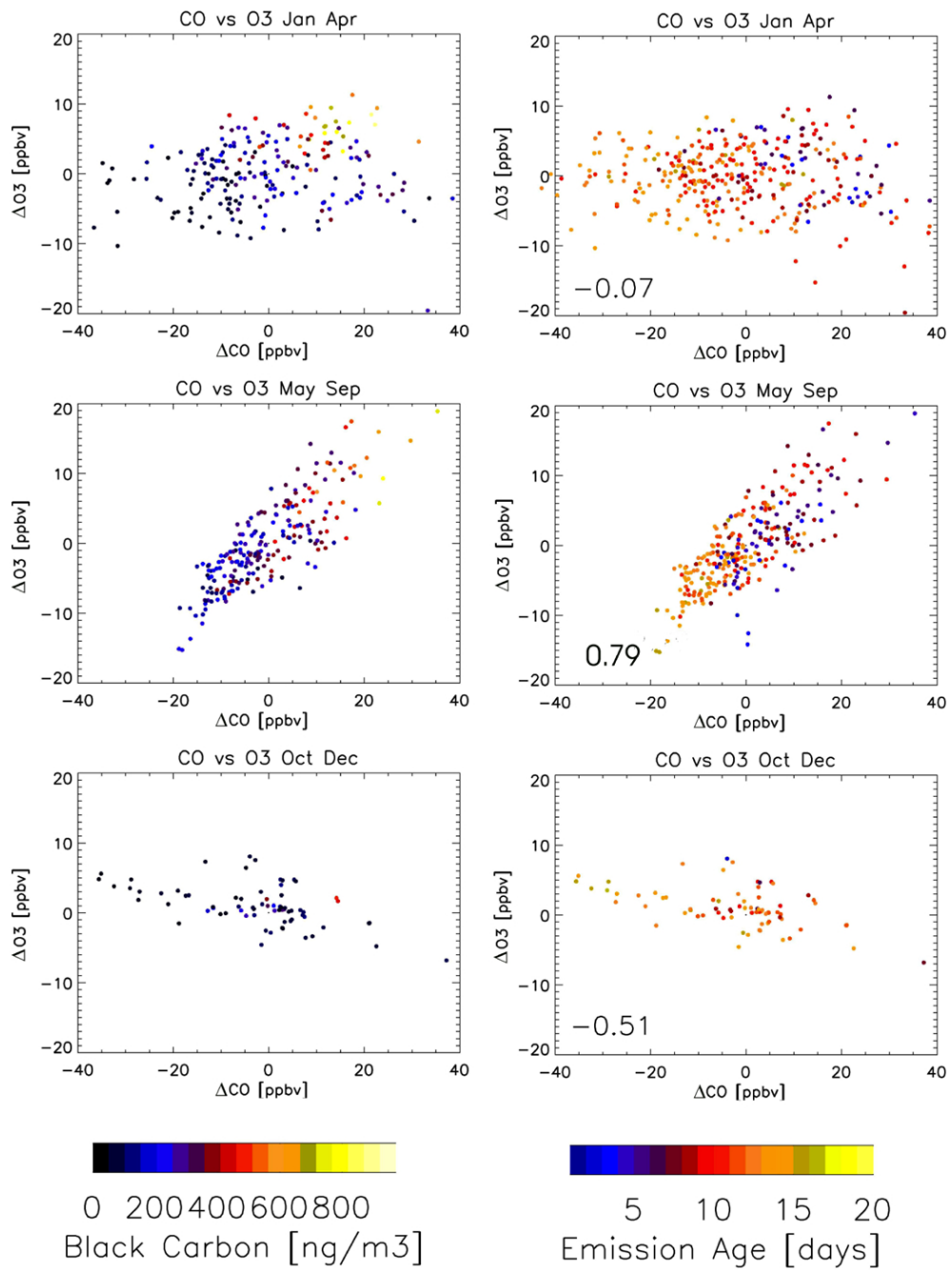

Fig. 8. Observed $\mathrm{CO}$ and $\mathrm{O}_{3}$ anomalies $\left(\Delta \mathrm{CO}\right.$ and $\Delta \mathrm{O}_{3}$ ) for January-April (top), May-September (middle) and October-December (bottom). Left column shows data tagged with $\mathrm{BC}$ concentrations observed at ICO-OV, while right column shows data tagged with emission age of $\mathrm{CO}_{\text {ant }}$ from FLEXPART. Linear correlation coefficients between $\Delta \mathrm{CO}$ and $\Delta \mathrm{O}_{3}(R)$ are reported for each plot in the left column. Data are averaged over a 24-h time window.

significantly contributed to the presence of the highest $\mathrm{O}_{3}$ and $\mathrm{CO}$ values observed at ICO-OV during late spring and summer. On the other hand, $\Delta \mathrm{O}_{3}$ is not correlated with $\Delta \mathrm{CO}$ during January-April $(R:-0.07)$. Nevertheless, the highest $\mathrm{BC}$ values ( $>400 \mathrm{ng} \mathrm{m}^{-3}$ ) were still observed together with positive $\Delta C O$ and $\Delta \mathrm{O}_{3}$. During October-December, $\Delta C O$ and $\Delta \mathrm{O}_{3}$ were negatively correlated $(R:-0.51)$ indicating reduced photochemical production and/or $\mathrm{O}_{3}$ depletion due to NO titration. In particular, positive $\Delta \mathrm{O}_{3}$ mostly coincides with negative $\triangle \mathrm{CO}$ and low $\mathrm{BC}$ values, indicating that clean air-masses, possibly from the free troposphere or the lower stratosphere (e.g. Cristofanelli et al., 2006) could lead to $\mathrm{O}_{3}$ increase during these months.

Figure 8 also shows that, for May-September, the greatest fraction of observations tagged to $\mathrm{CO}_{\text {ant }}<7$ days were mostly associated with enhanced $\Delta \mathrm{CO}, \Delta \mathrm{O}_{3}$ and BC. How- ever, positive $\mathrm{CO}$ and $\mathrm{O}_{3}$ anomalies with enhanced $\mathrm{BC}$ values were also present with older $\mathrm{CO}_{\text {ant }}$ emission age (up to 15 days), indicating that anthropogenic emissions occurring at very different temporal scales affected tracer values at ICOOV. In January-April, it is less straightforward to identify clear signatures of $\mathrm{CO}_{\text {ant }}$ emission age with observed atmospheric composition, even if positive $\Delta \mathrm{CO}$ still occur with younger $\mathrm{CO}_{\text {ant }}$ emission ages. However, the highest $\mathrm{BC}$ concentrations $\left(400 \mathrm{ng} \mathrm{m}^{-3}\right)$ were mostly associated with emission ages ranging from 7 to 11 days, thus suggesting a contribution by slower or farther polluted air-mass transport. From October to December, FLEXPART calculations do not show the presence of significant recent emissions (i.e. less than 5 days), indicating again that during these months ICO-OV is mostly influenced by emissions with longer times of atmospheric transport. 

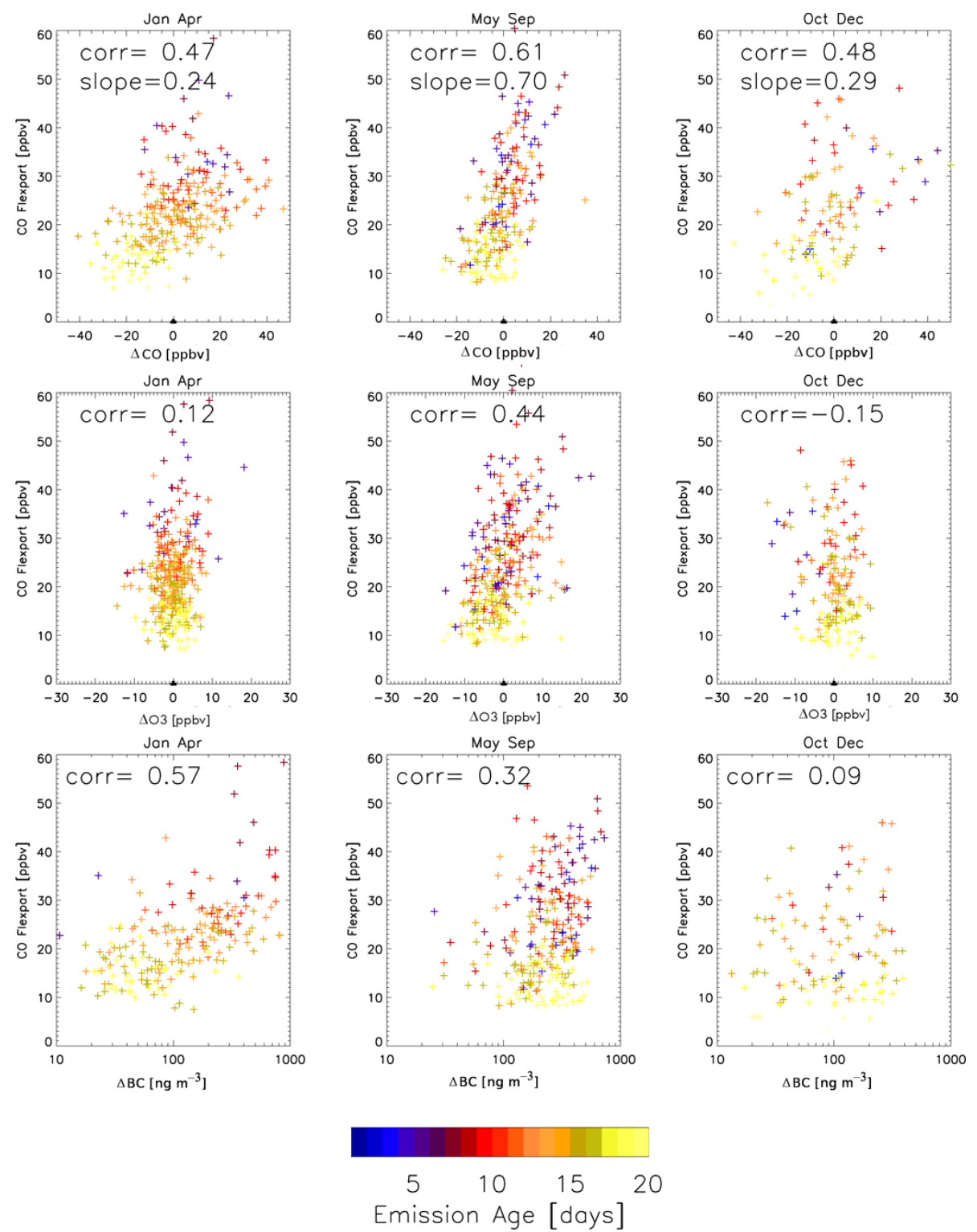

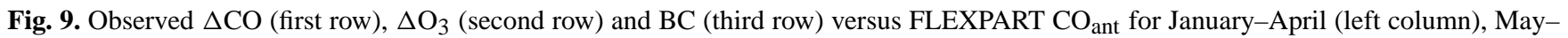
September (middle column) and October-December (right column). Data are averaged over $24 \mathrm{~h}$ and are tagged with emission age of $\mathrm{CO}_{\mathrm{ant}}$ (colored scale). The linear correlation coefficients (corr) is reported for all the scatter-plots while the slope values (slope) are only reported for the $\triangle \mathrm{CO}-\mathrm{CO}_{\text {ant }}$ correlation.

In order to quantify the amount of observed variability that can be ascribed to transport diagnosed by FLEXPART, Fig. 9 reports the seasonal correlation between $\triangle \mathrm{CO}, \Delta \mathrm{O}_{3}$ and $\mathrm{BC}$ with $\mathrm{CO}_{\mathrm{ant}}$ for 24-h time average. The days influenced by the $\mathrm{BB}$ transport events identified in the previous Section were not treated in this analysis. Correlation between FLEXPART $\mathrm{CO}_{\text {ant }}$ with observed $\triangle \mathrm{CO}$ increases with the length of the time averaging window between 3 and $24 \mathrm{~h}$ because the effect of short timing errors in modelled contributions is reduced by increasing the average time window. Correlations decrease for even longer averaging times, so we present the results obtained for the $24 \mathrm{~h}$ analysis. FLEXPART $\mathrm{CO}_{\text {ant }}$ correctly reproduce the absolute range of $\triangle \mathrm{CO}$ variability observed at ICO-OV (-30/30 ppb): in fact, as reported by Fig. 7, $\mathrm{CO}_{\text {ant }}$ ranged from 0 to $60 \mathrm{ppb}$. The slope of the linear correlation between $\triangle \mathrm{CO}$ and $\mathrm{CO}_{\text {ant }}$ varies from 0.24 (January-April) to 0.70 (May-September). The calculated $\Delta \mathrm{CO}-\mathrm{CO}_{\text {ant }}$ linear correlation coefficients $(R)$ are statistically significant at the $95 \%$ confidence level for all the seasonal aggregations. This suggests that an important fraction of the observed $\mathrm{CO}$ variability can be explained by anthropogenic emissions, especially in May-September when the strongest linear coefficient has been found $(R=0.61)$. 
Maximum $\mathrm{CO}_{\text {ant }}-\mathrm{O}_{3}$ correlation is also obtained in MaySeptember, indicating the important role of anthropogenic emissions for $\mathrm{O}_{3}$ formation during the warm months. As for $\Delta \mathrm{CO}$, the highest positive $\Delta \mathrm{O}_{3}$ were tagged to emissions younger than 5-7 days even if contribution from older emissions cannot be neglected, indicating that anthropogenic emissions transported on very different scales affected atmospheric composition at ICO-OV. In agreement with the results shown in Fig. 6, for $\Delta \mathrm{O}_{3}$ the linear correlation is negative (and significant at the $95 \%$ confidence level) during October-December and the few observations tagged to young anthropogenic emissions (blue dots) were generally characterised by negative $\Delta \mathrm{O}_{3}$ further stressing the possible role played by NO titration in the local-regional European PBL during these months.

For $\mathrm{BC}$, the linear correlation with $\mathrm{CO}_{\mathrm{ant}}$ is highest in January-April $(R: 0.57)$ : as suggested by FLEXPART it is likely that enhancement in aerosol concentrations is due to relatively aged anthropogenic emissions. Significant correlation can be seen also in May-September with BC enhancements above $400 \mathrm{ng} \mathrm{m}^{-3}$ mainly related to emission ages lower than 7 days. In October-December $\mathrm{BC}$ and $\mathrm{CO}_{\text {ant }}$ appear to be almost uncorrelated with $\mathrm{BC}$ concentrations never increased up to $300 \mathrm{ng} \mathrm{m}^{-3}$ and minimum values of $\mathrm{CO}_{\text {ant }}$ (see Fig. 6).

\section{Conclusions}

We quantified the variability of $\mathrm{O}_{3}, \mathrm{CO}$ and $\mathrm{BC}$ at the Mt. Cimone global GAW-WMO station (ICO-OV) and we investigated the influence of biomass burning (BB) and anthropogenic emissions younger than 20 days.

In 2007-2009, the average $\mathrm{O}_{3}, \mathrm{CO}$ and $\mathrm{BC}$ at ICO-OV were $54 \pm 3 \mathrm{ppb}, 122 \pm 7 \mathrm{ppb}$ and $213 \pm 34 \mathrm{ng} \mathrm{m}^{-3}$ (mean \pm expanded uncertainty with $p<95 \%$ ), with marked seasonal cycles characterized by summer maxima - winter minima for $\mathrm{O}_{3}$ and $\mathrm{BC}$, and a spring maximum - summer minimum for CO.

According to the FLEXPART simulations, impact of 20day old $\mathrm{BB}$ emissions is maximized during the warm months from May to September, however BB emissions traced back by FLEXPART had a significant impact on the observed tracers only during 16 specific events (21 days over the 30 months here considered). Very large variability of enhancement ratios for $\mathrm{O}_{3} / \mathrm{CO}$ and for $\mathrm{BC} / \mathrm{CO}$ were observed at ICOOV during these events even if we observed a general increasing (decreasing) trend of $\mathrm{O}_{3} / \mathrm{CO}(\mathrm{BC} / \mathrm{CO})$ with increasing emission ages.

As indicated by FLEXPART, 20-day old anthropogenic $\mathrm{CO}$ contributions can explain $17.4 \%$ of the mean $\mathrm{CO}$ value observed at ICO-OV during the investigating period, with the warm months (from April to September) appearing to be particularly affected by transport events of air-masses rich in anthropogenic CO. Overall, the correlation analysis of
ICO-OV tracers with $\mathrm{CO}_{\text {ant }}$ indicated that the fraction of observed variability ascribed to 20-day old anthropogenic emissions ranged from $22 \%$ (in January-April) to $37 \%$ (in MaySeptember) for $\Delta \mathrm{CO}$, from $1 \%$ (in October-December) to $19 \%$ (in May-September) for $\Delta \mathrm{O}_{3}$ and from less than $1 \%$ (in October-December) to $32 \%$ (in January-April) for BC.

The analysis of the seasonal correlation among $\mathrm{CO}, \mathrm{O}_{3}$ and $\mathrm{BC}$ observed at the ICO-OV as a function of the $\mathrm{CO}_{\text {ant }}$ emission age, allowed to identify three main regimes. During May-September, significant positive correlation $(R: 0.79)$ has been found for $\mathrm{CO}$ and $\mathrm{O}_{3}$, with the highest $\mathrm{CO}$ and $\mathrm{O}_{3}$ values observed in presence of high $\mathrm{BC}$ concentration $\left(>400 \mathrm{ng} \mathrm{m}^{-3}\right)$. On the other side, $\mathrm{CO}$ and $\mathrm{O}_{3}$ were negatively correlated $(R:-0.51)$ during October-December: such behaviour may be attributed to an ensemble of processes concurrent in enhancing $\mathrm{O}_{3}$ with low $\mathrm{CO}$ (i.e upper troposphere/lower stratosphere intrusions) and $\mathrm{O}_{3}$ titration with NO in polluted air-masses along with low photochemical activity. An intermediate situation occurs in January-April with $\mathrm{CO}$ and $\mathrm{O}_{3}$ almost uncorrelated and $\mathrm{BC}$ enhancements mainly associated to relatively old ( $>7$ days) anthropogenic emissions.

This work lead to the conclusion that trace gas and $\mathrm{BC}$ concentrations at the ICO-OV, which can be considered representative for $\mathrm{SE} / \mathrm{MB}$, are partially driven by local to global scale transport of anthropogenic emissions while, as diagnosed by FLEXPART, BB appeared to have a minor impact on the annual mean. However, it should be clear in mind that these values represent minimal estimates about BB influence, since FLEXPART cannot quantify the contributions coming from the well-mixed background. FLEXPART showed to be accurate in capturing long-range transport, including BB plume (e.g. Stohl et al., 1998, 2006, 2007; Forster et al., 2001; Damoah et al., 2006; Lapina et al., 2008), even if, especially for individual events of long-range $\mathrm{BB}$ transport, some uncertainties can affect the identification of the BB transport event at CMN, due to air-mass transport simulation, identification of fires and estimate of emissions. However, as also shown by MOPITT satellite measurements for two case studies of long-range BB transport, FLEXPART seems to be able in describing the impact of BB emissions. Nevertheless, further work is needed to explore the validity of the results here obtained for other sites in the SE/MB region, that can be affected by different transport patterns and/or emissions.

\section{Supplementary material related to this article is available online at: http://www.atmos-chem-phys.net/13/ 15/2013/acp-13-15-2013-supplement.pdf.}

Acknowledgements. The research presented in this paper has been supported by the SHARE (Stations at High Altitudes for Environmental Research) Project thanks to contributions from the Italian National Research Council and the Italian Ministry of Foreign 
Affairs and by ACTRIS, funded within the EC 7th Framework Programme under "Research Infrastructures for Atmospheric Research". Part of this work has been supported by the Project of National Interest NEXTDATA. MOPITT (Measurements of Pollution in the Troposphere) CO data were provided by NCAR by the web site http://www.acd.ucar.edu/mopitt/visualize.shtml.

Edited by: H. Wernli

\section{References}

Andreae, M. O. and Gelencsér, A.: Black carbon or brown carbon? The nature of light-absorbing carbonaceous aerosols, Atmos. Chem. Phys., 6, 3131-3148, doi:10.5194/acp-6-3131-2006, 2006.

Andreae, M. O. and Merlet, P.: Emission of trace gases and aerosols from biomass burning, Global Biogeochem. Cy., 15, 955-966, 2001.

Auvray, M. and Bay, I.: Long-range transport to Europe: Seasonal variations and implications for the European ozone budget, J. Geophys. Res., 110, D11303, doi:10.1029/2004JD005503, 2005.

Balis, D., Papayannis, A., Galani, E., Marenco, F., Santacesaria, V., Hamonou, E., Chazette, P., Ziomas, I., and Zerefos, C... Tropospheric LIDAR aerosol measurements and sun photometric observations at Thessaliniki, Greece, Atmos. Environ., 34, 925932, 2000.

Bertschi, I. T. and Jaffe, D. A.: Long-range transport of ozone, carbon monoxide, and aerosols to the NE Pacific troposphere during the summer of 2003: Observations of smoke plumes from Asian boreal fires, J. Geophys. Res., 110, D05303, doi:10.1029/2004JD005135, 2005.

Bonasoni, P., Stohl, A., Cristofanelli, P., Calzolari, F., Colombo, T., and Evangelisti, F.: Background ozone variations at Mt. Cimone Station, Atmos. Environ., 34, 5183-5189, 2000.

Bonasoni, P., Cristofanelli, P., Calzolari, F., Bonafè, U., Evangelisti, F., Stohl, A., Zauli Sajani, S., van Dingenen, R., Colombo, T., and Balkanski, Y.: Aerosol-ozone correlations during dust transport episodes, Atmos. Chem. Phys., 4, 1201-1215, doi:10.5194/acp4-1201-2004, 2004.

Bond, T. C., Streets, D. G., Yarber, K. F., Nelson, S. M., Woo, J.-H., and Klimont, Z.: A technology based global inventory of black carbon and organic carbon emissions from combustion, J. Geophys. Res., 109, D14203, doi:10.1029/2003JD003697, 2004.

Bond, T. C., Zarzycki, C., Flanner, M. G., and Koch, D. M.: Quantifying immediate radiative forcing by black carbon and organic matter with the Specific Forcing Pulse, Atmos. Chem. Phys., 11, 1505-1525, doi:10.5194/acp-11-1505-2011, 2011.

Conti, S., Meli, P., Minelli, G., Solimini, R., Toccaceli, V., Vichi, M., Beltrano, C., and Perini, L.: Epidemiologic study of mortality during the Summer 2003 heat wave in Italy, Environ. Res., 98, 390-399, 2005.

Chevalier, A., Gheusi, F., Delmas, R., Ordóñez, C., Sarrat, C., Zbinden, R., Thouret, V., Athier, G., and Cousin, J.-M.: Influence of altitude on ozone levels and variability in the lower troposphere: a ground-based study for western Europe over the period 2001-2004, Atmos. Chem. Phys., 7, 4311-4326, doi:10.5194/acp-7-4311-2007, 2007.

Chevalier, A., Gheusi, F., Attié, J.-L., Delmas, R., Zbinden, R., Athier, G., and Cousin, J.-M.: Carbon monoxide observations from ground stations in France and Europe and long trends in the free troposphere, Atmos. Chem. Phys. Discuss., 8, 3313-3356, doi:10.5194/acpd-8-3313-2008, 2008.

Cristofanelli, P., Bonasoni, P., Tositti, L., Bonafè, U., Calzolari, F., Evangelisti, F., Sandrini, S., and Stohl, A.: A 6-year analysis of stratospheric intrusions and their influence on ozone at Mt. Cimone (2165 m above sea level), J. Geophys. Res., 111, D03306, doi:10.1029/2005JD006553, 2006.

Cristofanelli, P., Bonasoni, P., Carboni, G., Calzolari, F., Casarola, L., Zauli Sajani, S., and Santaguida, R.: Anomalous high ozone concentrations recorded at a high mountain station in Italy in summer 2003, Atmos. Environ., 41, 1383-1394, 2007.

Cristofanelli, P., Marinoni, A., Arduini, J., Bonafè, U., Calzolari, F., Colombo, T., Decesari, S., Duchi, R., Facchini, M. C., Fierli, F., Finessi, E., Maione, M., Chiari, M., Calzolai, G., Messina, P., Orlandi, E., Roccato, F., and Bonasoni, P.: Significant variations of trace gas composition and aerosol properties at $\mathrm{Mt}$. Cimone during air mass transport from North Africa - contributions from wildfire emissions and mineral dust, Atmos. Chem. Phys., 9, 4603-4619, doi:10.5194/acp-9-4603-2009, 2009.

Crutzen, P. J. and Andreae, M. O.: Biomass burning in the tropics: Impact on atmospheric chemistry and biogeochemical cycles, Science, 250, 1669-1678, 1990.

Crutzen, P. J., Lawrence, M. G., and Pöschl, U.: On the background photochemistry of tropospheric ozone, Tellus, 51, 123146, 1999.

Damoah, R., Spichtinger, N., Servranckx, R., Fromm, M., Eloranta, E. W., Razenkov, I. A., James, P., Shulski, M., Forster, C., and Stohl, A.: A case study of pyro-convection using transport model and remote sensing data, Atmos. Chem. Phys., 6, 173185, doi:10.5194/acp-6-173-2006, 2006.

Duncan, B. N., West, J. J., Yoshida, Y., Fiore, A. M., and Ziemke, J. R.: The influence of European pollution on ozone in the Near East and northern Africa, Atmos. Chem. Phys., 8, 2267-2283, doi:10.5194/acp-8-2267-2008, 2008.

Fischer, H., Kormann, R., Klüpfel, T., Gurk, Ch., Königstedt, R., Parchatka, U., Mühle, J., Rhee, T. S., Brenninkmeijer, C. A. M., Bonasoni, P., and Stohl, A.: Ozone production and trace gas correlations during the June 2000 MINATROC intensive measurement campaign at Mt. Cimone, Atmos. Chem. Phys., 3, 725-738, doi:10.5194/acp-3-725-2003, 2003.

Flanner, M. G., Zender, C. S., Hess, P. G., Mahowald, N. M., Painter, T. H., Ramanathan, V., and Rasch, P. J.: Springtime warming and reduced snow cover from carbonaceous particles, Atmos. Chem. Phys., 9, 2481-2497, doi:10.5194/acp-9-24812009, 2009.

Forster, C., Wandinger, U., Wotawa, G., James, P., Mattis, I., Althausen, D., Simmonds, P., O'Doherty, S., Kleefeld, C., Jennings, S. G., Schneider, J., Trickl, T., Kreipl, S., Jäger, H., and Stohl, A.: Transport of boreal forest fire emissions from Canada to Europe, J. Geophys. Res., 106, 22887-22906, 2001.

Forster, P., Ramaswamy, V., Artaxo, P., Berntsen, T., Betts, R., Fahey, D. W., Haywood, J., Lean, J., Lowe, D. C., Myhre, G., Nganga, J., Prinn, R., Raga, G., Schulz, M., and Van Dorland, R.: Changes in Atmospheric Constituents and in Radiative Forcing, in Climate Change 2007: The Physical Science Basis. Contribution of Working Group I to the Fourth Assessment Report of the Intergovernmental Panel on Climate Change, edited by: Solomon, S., Qin, D., Manning, M., Chen, Z., Marquis, M., 
Averyt, K. B., Tignor M., and Miller, H. L., Cambridge University Press, Cambridge, United Kingdom and New York, NY, USA, 2007.

Frost, G. J., McKeen, S. A., Trainer, M., Ryerson, T. B., Neuman, J. A., Roberts, J. M., Swanson, A., Holloway, J. S., Sueper, D. T., Fortin, T., Parrish, D. D., Fehsenfeld, F. C., Flocke, F., Peckham, S. E., Grell, G. A., Kowal, D., Cartwright, J., Auerbach, N., and Habermann, T.: Effects of changing power plant $\mathrm{NO}_{\mathrm{x}}$ emissions on ozone in the eastern United States: Proof of concept, J. Geophys. Res., 111, D12306, doi:10.1029/2005JD006354, 2006.

Gauss, M., Myhre, G., Pitari, G., Prather, M., Isaksen, I. S. A., Berntsen, T. K., Brasseur, G. P., Dentener, F. J., Derwent, R. G., Hauglustaine, D. A., Horowitz, L. W., Jacob, D. J., Johnson, M., Law, K. S., Mickley, L. J., Müller, J.-F., Plantevin, P.-H., Pyle, J. A., Rogers, H. L., Stevenson, D. S., Sundet, J. K., van Weele, M., and Wild, O.: Radiative forcing in the 21 st century due to ozone changes in the troposphere and the lower stratosphere, J. Geophys. Res., 108, 4292, doi:10.1029/2002JD002624, 2003.

Giglio, L., Descloitres, J., Justice, C. O., and Kaufman, Y.: An enhanced contextual fire detection algorithm for MODIS, Remote Sens. Environ., 87, 273-282, 2003.

Gilge, S., Plass-Duelmer, C., Fricke, W., Kaiser, A., Ries, L., Buchmann, B., and Steinbacher, M.: Ozone, carbon monoxide and nitrogen oxides time series at four alpine GAW mountain stations in central Europe, Atmos. Chem. Phys., 10, 12295-12316, doi:10.5194/acp-10-12295-2010, 2010.

Harrison, S. P., Kohfeld, K. E., Roelandt, C., and Claquin, T.: The role of dust in climate changes today, at the Last Glacial Maximum and in the future, Earth Sci. Rev., 54, 43-80, 2001.

He, S. and Carmichael, G. R.: Sensitivity of photolysis rates and ozone production in the troposphere to aerosol properties, J. Geophys. Res., 104, 26307-26324, 1999.

Henne, S., Dommen, J., Neininger, B., Reimann, S., Staehelin, J., and Prèvôt, A. S. H.: Influence of mountain venting in the Alps on the ozone chemistry of the lower free troposphere and the European pollution export, J. Geophys. Res., 110, D22307, doi:10.1029/2005JD005936, 2005.

Honrath, R. E., Owen, R. C., Val Martın, M., Reid, J. S., Lapina, K., Fialho, P., Dziobak, M. P., Kleissl, J., and Westphal, D. L.: Regional and hemispheric impacts of anthropogenic and biomass burning emissions on summertime $\mathrm{CO}$ and $\mathrm{O}_{3}$ in the North Atlantic lower free troposphere, J. Geophys. Res., 109, D24310, doi:10.1029/2004JD005147, 2004.

Huntrieser, H., Heland, J., Schlager, H., Forster, C., Stohl, A., Aufmhoff, H., Arnold, F., Scheel, H. E., Campana, M., Gilge, S., Eixmann, R., and Cooper, O.: Intercontinental air pollution transport from North America to Europe: Experimental evidence from airborne measurements and surface observations, J. Geophys. Res., 110, D01305, doi:10.1029/2004JD005045, 2005.

Justice, C. O., Giglio, L., Korontzi, S., Owens, J., Morisette, J. T., Roy, D., Descloitres, J., Alleaume, S., Petitcolin, F., and Kaufman, Y.: The MODIS fire products, Remote Sens. Environ., 83, 244-262, 2002.

Kaneyasu, N., Igarashi, Y., Sawa, Y., Takahashi, H., Takada, H., Kumata, H., and Holler, R.: Chemical and optical properties of 2003 Siberian forest fire smoke observed at the summit of Mt. Fuji, Japan, J. Geophys. Res., 112, D13214, doi:10.1029/2007JD008544, 2007.
Kondo, Y., Matsui, H., Moteki, N., Sahu, L., Takegawa, N., Kajino, M., Zhao, Y., Cubison, M. J., Jimenez, J. L., Vay, S., Diskin, G. S., Anderson, B., Wisthaler, A., Mikoviny, T., Fuelberg, H. E., Blake, D. R., Huey, G., Weinheimer, A. J., Knapp, D. J., and Brune, W. H.: Emissions of black carbon, organic, and inorganic aerosols from biomass burning in North America and Asia in 2008, J. Geophys. Res., 116, D08204, doi:10.1029/2010JD015152, 2011.

Lapina, K., Honrath, R. E., Owen, R. C., Val Martìn, M., Hyer, E. J., and Fialho, P.: Late summer changes in burning conditions in the boreal regions and their implications for $\mathrm{NO}_{\mathrm{x}}$ and CO emissions from boreal fires, J. Geophys. Res., 113, D11304, doi:10.1029/2007JD009421, 2008.

Lelieveld, J., Berresheim, H., Borrmann, S., Crutzen, P. J., Dentener, F. J., Fischer, H., Feichter, J., Flatau, P. J., Heland, J., Holzinger, R., Kormann, R., Lawrence, M. B., Levin, Z., Markowicz, K., Mihalopoulos, N., Minikin, A., Ramanthan, V., de Reus, M., Roelofs, G. J., Scheeren, H. A., Sciare, J., Schlager, H., Schulz, M., Siegmund, P., Steil, B., Stephanou, E. G., Stier, P., Traub, M., Warneke, C., Williams, J., and Ziereis, H.: Global air pollution crossroads over the Mediterranean, Science, 298, 794-799, 2002.

Lohmann, U., Feichter, J., Penner, J. E., and Leaitch, W. R.: Indirect effect of sulfate and carbonaceous aerosols: A mechanistic treatment, J. Geophys. Res., 105, 12193-12206, 2000.

Marinoni, A., Cristofanelli, P., Calzolari, F., Roccato, F., Bonafè, U., and Bonasoni, P.: Continuous measurements of aerosol physical parameters at the Mt. Cimone GAW Station (2165 m asl, Italy), Sci. Total Environ., 391, 241-251, 2008.

Millàn, M., Sanz, J., Salvador, R., and Mantilla, E.:. Atmospheric dynamics and ozone cycles related to nitrogen deposition in the western Mediterranean, Environ. Poll., 118, 167-186, 2006.

Monks, P.: A review of the observations and origins of the spring maximum, Atmos. Environ, 34, 3545-3561, 2000.

Monks, P. S., Granier, C., Fuzzi, S., Stohl, A., Williams, M. L., Akimoto, H., Amann, M., Baklanov, A., Baltensperger, U., Bey, I., Blake, N., Blake, R. S., Carslaw, K., Cooper, O. R., Dentener, F., Fowler, D., Fragkou, E., Frost, G. J., Generoso, S., Ginoux, P., Grewe, V., Guenther, A., Hansson, H. C., Henne, S., Hjorth, J., Hofzumahaus, A., Huntrieser, H., Isaksen, I. S. A., Jenkin, M. E., Kaiser, J., Kanakidou, M., Klimont, Z., Kulmala, M., Laj, P., Lawrence, M. G., Lee, J. D., Liousse, C., Maione, M., McFiggans, G., Metzger, A., Mieville, A., Moussiopoulos, N., Orlando, J. J., O’Dowd, C. D., Palmer, P. I., Parrish, D. D., Petzold, A., Platt, U., Pöschl, U., Prévôt, A. S. H., Reeves, C. E., Reimann, S., Rudich, Y., Sellegri, K., Steinbrecher, R., Simpson, D., ten Brink, H., Theloke, J., van der Werf, G. R., Vautard, R., Vestreng, V., Lachokostas, Ch., and von Glasow, R.: Atmospheric composition change - global and regional air quality, Atmos. Environ., 43, 5268-5350, 2009.

Novelli, P. C.: CO in the atmosphere: measurement techniques and related issues, Chemosphere, Global Change Sci., 1, 115-126, 1999.

Novelli, P. C., Masarie, K. A., Lang, P. M., Hall, B. D., Myers, R. C., and Elkins, J. W.: Reanalysis of tropospheric CO trends: Effects of the 1997-1998 wildfires, J. Geophys. Res., 108, 4464, doi:10.1029/2002JD003031, 2003.

Pace, G., di Sarra, A., Meloni, D., Piacentino, S., and Chamard, P.: Aerosol optical properties at Lampedusa (Central 
Mediterranean). 1. Influence of transport and identification of different aerosol types, Atmos. Chem. Phys., 6, 697-713, doi:10.5194/acp-6-697-2006, 2006.

Pan, X. L., Kanaya, Y., Wang, Z. F., Liu, Y., Pochanart, P., Akimoto, H., Sun, Y. L., Dong, H. B., Li, J., Irie, H., and Takigawa, M.: Correlation of black carbon aerosol and carbon monoxide in the high-altitude environment of Mt. Huang in Eastern China, Atmos. Chem. Phys., 11, 9735-9747, doi:10.5194/acp-11-97352011, 2011.

Petzold, A., Kramer, H., and Schönlinner, M.: Continuous measurement of atmospheric black carbon using a multi-angle absorption photometer, Environ. Sci. Pollut. Res., 4, 78-82, 2002.

Pfister, G., Petron, G., Emmons, L. K., Gille, J. C., Edwards, D. P., Lamarque, J. F., Attie, J. L., Granier, C., and Novelli, P. C.: Evaluation of CO simulations and the analysis of the CO budget for Europe, J. Geophys. Res.-Atmos., 109, D19304, doi:10.1029/2004JD004691, 2004.

Putaud, J.-P., Raes, F., Van Dingenen, R., Bruggemann, E., Facchini, M. C., Decesari, S., Fuzzi, S., Gehrig, R., Huglin, C., Laj, P., Lorbeer, G., Maenhaut, W., Mihalopoulos, N., Muller, K., Querol, X., Rodriguez, S., Schneider, J., Spindler, G,, Ten Brink, H., Torseth, K., and Wiedensohler, A.: A European aerosol phenomenology - 2: chemical characteristics of particulate matter at kerbside, urban, rural and background sites in Europe, Atmos. Environ., 38, 2579-2595, 2004.

Real, E., Law, K. S., Weinzierl, B., Fiebig, M., Petzold, A., Wild, O., Methven, J., Arnold, S., Stohl, A., Huntrieser, H., Roiger, A., Schlager, H., Stewart, D., Avery, M., Sachse, G., Browell, E., Ferrare, R., and Blake, D.: Processes influencing ozone levels in Alaskan forest fire plumes during long-range transport over the North Atlantic, J. Geophys. Res., 112, D10S41, doi:10.1029/2006JD007576, 2007.

Seinfeld, J. H. and Pandis, S. N.: Atmospheric chemistry and physics: from air pollution to climate change, WileyInterscience, 1326 pp., New York, USA, 1998.

Simmonds, P., Manning, A., Derwent, R., Ciais, P., Ramonet, M., Kazan, V., and Ryall, D.: A burning question: Can recent growth rate anomalies in the greenhouse gases be attributed to large scale biomass burning events?, Atmos. Environ., 39, 2513-2517, doi:10.1016/j.atmosenv.2005.02.018, 2005.

Solomon, S., Qin, D., Manning, M., Alley, R. B., Berntsen, T., Bindoff, N. L., Chen, Z., Chidthaisong, A., Gregory, J. M., Hegerl, G. C., Heimann, M., Hewitson, B., Hoskins, B. J., Joos, F., Jouzel, J., Kattsov, V., Lohmann, U., Matsuno, T., Molina, M., Nicholls, N., Overpeck, J., Raga, G., Ramaswamy, V., Ren, J., Rusticucci, M., Somerville, R., Stocker, T. F., Whetton, P.,Wood R. A., and Wratt, D.:: Technical Summary, in Climate Change 2007: The Physical Science Basis. Contribution of Working Group I to the Fourth Assessment Report of the Intergovernmental Panel on Climate Change, edited by: Solomon, S., Qin D., Manning M., Chen Z., Marquis, M., Averyt K. B., Tignor, M., and Miller, H. L., Cambridge University Press, Cambridge, United Kingdom and New York, NY, USA, 2007.

Stohl, A. and Trickl, T.: A textbook example of long-range transport: Simultaneous observation of ozone maxima of stratospheric and North American origin in the free troposphere over Europe, J. Geophys. Res., 104, 30445-30462, 1999.

Stohl, A., Hittenberger, M., and Wotawa, G., Validation of the Lagrangian particle dispersion model FLEXPART against largescale tracer experiment data, Atmos. Environ., 32, 42454264, 1998.

Stohl, A., Spichtinger-Rakowsky, N., Bonasoni, P., Feldmann, H., Memmesheimer, M., Scheel, H. E., Trickl, T., Huebener, S. H., Ringer, W., and Mandl, M.: The influence of stratospheric intrusions on alpine ozone concentrations, Atmos. Environ, 34, 13231354, 2000.

Stohl, A., Huntrieser, H., Richter, A., Beirle, S., Cooper, O. R., Eckhardt, S., Forster, C., James, P., Spichtinger, N., Wenig, M., Wagner, T., Burrows, J. P., and Platt, U.: Rapid intercontinental air pollution transport associated with a meteorological bomb, Atmos. Chem. Phys., 3, 969-985, doi:10.5194/acp-3-969-2003, 2003.

Stohl, A., Forster, C., Frank, A., Seibert, P., and Wotawa, G.: Technical note: The Lagrangian particle dispersion model FLEXPART version 6.2, Atmos. Chem. Phys., 5, 2461-2474, doi:10.5194/acp-5-2461-2005, 2005.

Stohl, A., Andrews, E., Burkhart, J. F., Forster, C., Herber, A., Hoch, S. W. , Kowal, D., Lunder, C., Mefford, T., Ogren, J. A., Sharma, S., Spichtinger, N., Stebel, K., Stone, R., Ström, J., Tørseth, K., Wehrli, C., and Yttri, K. E.: Pan-Arctic enhancements of light absorbing aerosol concentrations due to North American boreal forest fires during summer 2004, J. Geophys. Res., 111, D22214, doi:10.1029/2006JD007216, 2006.

Stohl, A., Berg, T., Burkhart, J. F., Fjae'raa, A. M., Forster, C., Herber, A., Hov, Ø., Lunder, C., McMillan, W. W., Oltmans, S., Shiobara, M., Simpson, D., Solberg, S., Stebel, K., Ström, J., Tørseth, K., Treffeisen, R., Virkkunen, K., and Yttri, K. E.: Arctic smoke - record high air pollution levels in the European Arctic due to agricultural fires in Eastern Europe in spring 2006, Atmos. Chem. Phys., 7, 511-534, doi:10.5194/acp-7-511-2007, 2007.

Trickl, T., Cooper, O. R., Eisele, H., James, P., Mücke, R., and Stohl, A.: Intercontinental transport and its influence on the ozone concentrations over central Europe: Three case studies, J. Geophys. Res., 108, 8530, doi:10.1029/2002JD002735, 2003.

Turquety, S., Hurtmans, D., Hadji-Lazaro, J., Coheur, P.-F., Clerbaux, C., Josset, D., and Tsamalis, C.: Tracking the emission and transport of pollution from wildfires using the IASI CO retrievals: analysis of the summer 2007 Greek fires, Atmos. Chem. Phys., 9, 4897-4913, doi:10.5194/acp-9-4897-2009, 2009.

Val Martin, M., Honrath, R. E., Owen, R. C., Pfister, G., Fialho, P., and Barata, F.: Significant enhancements of nitrogen oxides, black carbon, and ozone in the North Atlantic lower free troposphere resulting from North American boreal wildfires, J. Geophys. Res., 111, D23S60, doi:10.1029/2006JD007530, 2006.

van der Werf, G. R., Randerson, J. T., Giglio, L., Collatz, G. J., Kasibhatla, P. S., and Arellano Jr., A. F.: Interannual variability in global biomass burning emissions from 1997 to 2004, Atmos. Chem. Phys., 6, 3423-3441, doi:10.5194/acp-6-3423-2006, 2006.

Van Dingenen, R., Putaud, J.-P., Martins-Dos Santos, S., and Raes, F.: Physical aerosol properties and their relation to air mass origin at Monte Cimone (Italy) during the first MINATROC campaign, Atmos. Chem. Phys., 5, 2203-2226, doi:10.5194/acp-52203-2005, 2005.

Vautard, R., Honoré, C., Beekmann, M., and Rouil, L.: Simulation of ozone during the August 2003 heat wave and emission control scenarios, Atmos. Environ., 39, 2957-2967, 2005. 
Vingarzan, R.: A review of surface ozone background levels and trends, Atmos. Environ., 38, 3431-3442, 2004.

Volz-Thomas, A., Beekmann, M., Derwent, D., Law, K., Lindskog, A., Prevot, A., Roemer, M., Schultz, M., Schurath, U., Solberg S., and Stohl, A.: Tropospheric Ozone and its Control, in: Towards Cleaner Air for Europe - Science, Tools and Applications. Part 1: Results from the EUROTRAC-2; Synthesis and Integration (S\&I) Project, edited by: Builtjes, P. J.-H., Harrison, R. M., Midgley, P. M., and Tørsen, K., International Scientific Secretariat, Munchen, Germany, 73-122, 2002.

Warneke, C., Bahreini, R., Brioude, J., Brock, C. A., de Gouw, J. A., Fahey, D. W., Froyd, K. D., Holloway, J. S., Middlebrook, A., Miller, L., Montzka, S., Murphy, D. M., Peischl, J., Ryerson, T. B. , Schwarz, J. P., Spackman, J. R., and Veres, P.: Biomass burning in Siberia and Kazakhstan as an important source for haze over Alaskan Arctic in April 2008, Geophys. Res. Lett., 36, L02813, doi:10.1029/2008GL036194, 2009.

World Meteorological Organization (WMO): Global Atmospheric Watch measurement guide, Tech. Doc. 1073, GAW Rep. 143, Geneva, Switzerland, 2002.
World Meteorological Organization (WMO): WMO WDCGG data summary, WDCGG No. 35, Japan Meteorological Agency, 2011.

Yurganov, L., Grechko, E., and Dzola, A.: Zvenigorod carbon monoxide total column time series: $27 \mathrm{yr}$ of measurements, Chemosphere: Global Changing Science, 1, 127-136, 1999.

Yurganov, L. N., Duchatelet, P., Dzhola, A. V., Edwards, D. P., Hase, F., Kramer, I., Mahieu, E., Mellqvist, J., Notholt, J., Novelli, P. C., Rockmann, A., Scheel, H. E., Schneider, M., Schulz, A., Strandberg, A., Sussmann, R., Tanimoto, H., Velazco, V., Drummond, J. R., and Gille, J. C.: Increased Northern Hemispheric carbon monoxide burden in the troposphere in 2002 and 2003 detected from the ground and from space, Atmos. Chem. Phys., 5, 563-573, doi:10.5194/acp-5-563-2005, 2005.

Zellweger, C., Hüglin, C., Klausen, J., Steinbacher, M., Vollmer, M., and Buchmann, B.: Inter-comparison of four different carbon monoxide measurement techniques and evaluation of the long-term carbon monoxide time series of Jungfraujoch, Atmos. Chem. Phys., 9, 3491-3503, doi:10.5194/acp-9-3491-2009, 2009. 